\title{
Using soil water isotopes to infer the influence of contrasting urban green space on ecohydrological partitioning
}

\author{
Lena-Marie Kuhlemann ${ }^{1,2}$, Doerthe Tetzlaff ${ }^{1,2,3}$, Aaron Smith ${ }^{1}$, Birgit Kleinschmit ${ }^{4}$, and Chris Soulsby ${ }^{3,5,1}$ \\ ${ }^{1}$ Department of Ecohydrology, Leibniz Institute of Freshwater Ecology and Inland Fisheries, \\ Müggelseedamm 310, 12587 Berlin, Germany \\ ${ }^{2}$ Department of Geography, Humboldt University of Berlin, Rudower Chaussee 16, 12489 Berlin, Germany \\ ${ }^{3}$ Northern Rivers Institute, University of Aberdeen, St. Mary's Building, Kings College, Old Aberdeen, AB24 3 UE, Scotland \\ ${ }^{4}$ Institute of Landscape Architecture and Environmental Planning, Technical University Berlin, \\ Straße des 17. Juni 145, 10623 Berlin, Germany \\ ${ }^{5}$ Chair of Water Resources Management and Modeling of Hydrosystems, Technical University Berlin, \\ Gustav-Meyer-Allee 25, 13355 Berlin, Germany
}

Correspondence: Lena-Marie Kuhlemann (kuhlemann@igb-berlin.de)

Received: 19 August 2020 - Discussion started: 11 September 2020

Revised: 15 December 2020 - Accepted: 15 January 2021 - Published: 24 February 2021

\begin{abstract}
In cities around the world, urban green spaces provide a range of benefits and ecosystem services. However, recent years have shown how prolonged warm and dry periods can affect urban water resources and lead to water stress in vegetation in urban green spaces, even in temperate regions. Consequently, quantitative knowledge about ecohydrological partitioning in different types of urban green space is crucial for balancing sustainable water needs in cities during future challenges of increasing urbanization and climate warming. Using isotopic tracers in precipitation and soil water, along with conventional hydrometric measurements in a plot-scale study in Berlin, Germany, we investigated water partitioning under different generic types of urban vegetation (grassland, shrub and trees). This allowed for the assessment of urban vegetation effects on evapotranspiration, subsurface flow paths and storage during a prolonged drought period with episodic rainfall. Despite higher soil evaporation losses under urban grassland, higher interception and transpiration likely contributed to slower turnover of soil water and older groundwater recharge under urban trees. Shrub vegetation seemed to be most resilient to prolonged drought periods, with lower evapotranspiration losses. Our results contribute to a better understanding of ecohydrological partitioning under mixed urban vegetation communities and an evidence base for better adaptive management of urban water and irrigation strate-
\end{abstract}

gies to sustainably meet the water demands of urban green spaces in the future.

\section{Introduction}

In many cities, hydrology and ecosystem services underpinning sustainable living are closely interlinked (Pataki et al., 2011a). Particularly urban green spaces in cities can provide a range of potential benefits (Nouri et al., 2013, 2019). Urban green infrastructure like green roofs or retention systems can enhance urban groundwater recharge and the infiltration of floodwaters (McGrane, 2016; Fletcher et al., 2013). In addition, more extensive natural urban green spaces like urban parks can increase biodiversity and habitat connectivity and provide numerous socio-economic benefits (Nouri et al., 2013; McGrane, 2016). In terms of ecohydrological partitioning, vegetation cover primarily affects urban evapotranspiration (ET; e.g. Fletcher et al., 2013; Peters et al., 2011; Pataki et al., 2011b) and can provide a cooling effect, mitigating urban heat islands (UHIs; e.g. Gunawardena et al., 2017). Especially in (semi-)arid areas where the preservation of urban green spaces requires irrigation, many cities are already facing water shortages, and meeting the water demands of this diversity of urban green spaces can be challenging (Nouri et al., 2013, 2019; Miller et al., 2020). In more 
temperate regions, the maintenance of urban green spaces has so far not required such extensive irrigation. However, an increasing number of exceptionally warm and dry summers in recent years has strongly impacted less droughtadapted ecosystems in central and northern Europe (Buras et al., 2020), and, consequently, the need for irrigation of urban green spaces may increase in temperate regions in the future. Therefore, understanding how urban vegetation uses and partitions water is crucial for implementing and adapting future urban water management and irrigation strategies to these conditions.

Studying water cycling in urban areas is often challenging. The urban water cycle is highly complex and comprises natural and engineered system components that alter the partitioning and routing of precipitation (Gessner et al., 2014; McGrane, 2016). The spatial distribution of contrasting urban land cover with surfaces of different permeabilities forms a highly heterogeneous mosaic that impacts infiltration and subsurface flow paths (Fletcher et al., 2013; Pataki et al., 2011a; Schirmer et al., 2013). Urban soils are often compacted and disturbed by the preferential routing of subsurface infrastructure (pipes, cables, etc.) and contain constructionbased fill materials and rubble (Endreny, 2005). Additionally, vegetation types of different heights, microclimates and water requirements are often heterogeneously distributed across these complex, anthropogenically altered landscapes (Nouri et al., 2013). Consequently, the ecohydrological function of urban green spaces likely differs from more natural vegetation (McGrane, 2016; Pataki et al., 2011b), and process understanding from rural areas may not be transferable (Vico et al., 2014). For example, urban forests are often a mix of native and non-native species (Pataki et al., 2011b) and regularly have to adapt to harsh environments with limited water availability where surface sealing is extensive (Bijoor et al., 2011; Vico et al., 2014) and a modified radiation and thermal regime from shading by tall buildings (Asawa et al., 2017). Impervious cover, artificial irrigation and the UHI can extend the length of the growing season (Zipper et al., 2016) and increase urban plant water requirements, thereby posing a risk for dry-season water stress (Zipper et al., 2017).

Though recent studies have contributed to an improved understanding of urban ecohydrology, there are still considerable knowledge gaps. Especially quantifying more natural processes contributing to urban water partitioning remains challenging (Pataki et al., 2011a). This includes the need for better quantification of ET from contrasting urban vegetation communities (Pataki et al., 2011a, b; Nouri et al., 2013) and a better understanding of urbanization impacts on spatio-temporal variations in infiltration, subsurface flow paths and groundwater recharge (Schirmer et al., 2013; McGrane, 2016; Pataki et al., 2011a). Quantifying these impacts to sustainably manage urban vegetation types and their distribution and placement in the surrounding environment will be crucial for adapting urban water management to meet the water demand of green spaces during projected climate warming and changing precipitation patterns (Nouri et al., 2013, 2016; Pataki et al., 2011b; Vico et al., 2014; Zipper et al., 2017).

A useful tool to disentangle water fluxes and constrain flow paths in complex landscapes is the application of isotopic tracers. Stable isotopes in water behave conservatively and can provide valuable insights into water cycling at various spatio-temporal scales (e.g. Clark and Fritz, 1997; Kendall and McDonnell, 1998). In recent years, they have increasingly been applied to understand water partitioning at the soil-plant-atmosphere interface (Sprenger et al., 2016, 2019b), particularly the effects of seasonality and different soil and vegetation types (e.g. Geris et al., 2015; Sprenger et al., 2017; Oerter and Bowen, 2019). In droughtsensitive rural areas near Berlin in northern Germany, fieldbased isotope and hydroclimatic measurements (Kleine et al., 2020) and integration of tracer data into process-based models (Douinot et al., 2019; Smith et al., 2020) revealed higher ET losses and lower groundwater recharge under forest than grassland cover. However, comparable studies are scarce in urban areas, where the application of isotope tracers remains a major research frontier (Ehleringer et al., 2016). One of the first studies using isotopes in urban green spaces suggested groundwater and irrigation as water sources for trees in Los Angeles (Bijoor et al., 2011). Others found that trees in the Salt Lake Valley utilized irrigation water during the growing season, though contributions of preceding winter precipitation could always be detected (Gómez-Navarro et al., 2019). Oerter and Bowen (2017) used in situ isotope measurements in irrigated urban soils in Utah and observed partitioning of soil water into mobile and immobile "pools". While these studies demonstrate the potential of isotope tracers in urban applications, there remains a need to address research gaps in understanding water partitioning, not only by irrigated urban trees, but also under the complex mosaic of more natural vegetation types distributed across urban landscapes.

To address this, we undertook a study in Berlin, Germany, a city characterized by a high cover of urban green and blue spaces, with $\sim 20 \%$ of forest/public green space and $7 \%$ surface waters (SenUVK, 2019a). Berlin's water demand is met by local resources (Limberg, 2007; Möller and Burgschweiger, 2008), and climate projections indicate warmer and drier conditions within the next century, accompanied by an increasing UHI (Langendijk et al., 2019). Therefore, improved knowledge of urban water partitioning is essential to optimize future benefits from the city's water resources and adapt to more integrated land and water management strategies. Our work focused on plot-scale research at an ecohydrological observatory in Berlin-Steglitz, which provides examples of non-irrigated main functional urban vegetation types (grassland, shrub and trees) and an opportunity to assess how they affect ecohydrological partitioning. Our specific objectives are to monitor these different urban soil-vegetation units by (i) quantitatively assessing ecohydrological partitioning through hydrometric and hydro- 
Table 1. Main plant species covering the three sampling plots and their approximate heights and estimated mean leaf area index (LAI) ranges over the study period in the different vegetation plots.

\begin{tabular}{llll}
\hline Site & Vegetation cover & $\begin{array}{l}\text { Vegetation } \\
\text { height }\end{array}$ & $\begin{array}{r}\text { Estimated } \\
\text { LAI }\end{array}$ \\
\hline \multirow{2}{*}{ Grassland } & $\begin{array}{l}\text { Arrhenatherum elatius } \\
\text { Moss }\end{array}$ & $<0.5 \mathrm{~m}$ & $2-3$ \\
\hline \multirow{3}{*}{ Shrub } & $\begin{array}{l}\text { Leaf litter } \\
\text { Clematis, Hedera helix }\end{array}$ & $<0.5 \mathrm{~m}$ & \multirow{2}{*}{$2-4$} \\
\cline { 2 - 3 } & Rubus armeniacus & 0.5 to $1 \mathrm{~m}$ & \\
\cline { 2 - 3 } & Young trees (Acer platanoides, Acer pseudoplatanus) & 2 to $3 \mathrm{~m}$ & \\
\hline \multirow{3}{*}{ Trees } & $\begin{array}{l}\text { Leaf litter } \\
\text { Hedera helix, Allium ursinum }\end{array}$ & $\begin{array}{l}\text { Various tree species of more than 100 years of age (including oak, } \\
\text { birch, plane, maple, elm, pine, chestnut, ash, lime tree, larch) }\end{array}$ & 10 to $>20 \mathrm{~m}$ \\
\cline { 2 - 3 } & $\begin{array}{l}\text { Some shrub and smaller trees (Prunus padus, Sambucus nigra, } \\
\text { Euonymus europaeus, Symphoricarpos, Ligustrum vulgare, } \\
\text { Anemone nemorosa, Mahonia) }\end{array}$ & \multirow{2}{*}{0.5 to $1.5 \mathrm{~m}$} \\
\end{tabular}

climatic measurements, (ii) determining the isotopic composition of precipitation and soil water to trace ecohydrological partitioning effects, (iii) inferring water ages and travel times of water in the unsaturated zone and (iv) discussing wider implications for the upscaling of these findings.

\section{Study site}

Germany's capital Berlin covers $891 \mathrm{~km}^{2}$, with a population of 3.64 million (Amt für Statistik Berlin-Brandenburg, 2020; Fig. 1). Located within the Northern European Plain, Berlin's flat topography was formed during the Pleistocene glaciation and primarily consists of Quaternary deposits of unconsolidated sediments (Stackebrandt and Manhenke, 2010). The NE-SW-trending sand and gravel deposits of the BerlinWarsaw glacial spillway are surrounded by the elevated plateaus of Barnim and Teltow in the north and south, covered by subglacial till (Limberg and Thierbach, 1997; Limberg, 2007). Groundwater flow in Berlin's $\sim 150 \mathrm{~m}$ thick freshwater aquifer of Tertiary-Holocene age (Limberg and Thierbach, 1997) is directed from the plateaus towards the rivers Spree and Havel in the glacial valley (velocities $\sim 10$ $500 \mathrm{~m} / \mathrm{yr}$; Limberg, 2007). Berlin meets its water demand through a semi-closed water cycle, whereby groundwater is abstracted from local storage and bank filtration, while treated sewage water is discharged back into the surface waters (Limberg and Thierbach, 1997; Limberg, 2007; Möller and Burgschweiger, 2008).

Recharge is low due to high area-weighted ET of $367 \mathrm{~mm} / \mathrm{yr}$ (60\% of precipitation), plus $152 \mathrm{~mm} / \mathrm{yr}$ evaporation from surface waters (SenStadtWoh, 2019). Long-term mean annual rainfall (1981-2010) from weather stations of the German Weather Service (DWD) is $525-602 \mathrm{~mm}$ and long-term mean annual air temperature $9.3-10.2^{\circ} \mathrm{C}$ (DWD, 2020b). Berlin's land use includes $34 \%$ sealed urban surfaces (SenStadtWoh, 2017) but also extensive urban green spaces, including forests (18.1\%), public parks $(12.2 \%)$ and agricultural areas (4.2\%; SenUVK, 2019a). Berlin has a high coverage of surface water bodies (Gerstengarbe et al., 2003), accounting for $\sim 7 \%$ of the city area (SenUVK, 2019a).

The Steglitz urban ecohydrological observatory (SUEO) is located on the Teltow plateau, in the SW of the city (Fig. 1). The surrounding district is covered by residential areas and roads $(55 \%)$, forest $(24 \%)$, water bodies $(11 \%)$ and public green space (9\%; SenUVK, 2019b). The SUEO itself comprises a $\sim 8000 \mathrm{~m}^{2}$ large research garden. The elevation is $\sim$ $45 \mathrm{~m}$ a.s.l. (SenStadt, 2010b), and groundwater levels are 10$15 \mathrm{~m}$ below surface (m b.s.; SenStadt, 2010a). Buildings and some older trees were established $>100$ years ago, though the current garden dates to the 1950s when the Technical University (TU) Berlin started using the site (Bornkamm and Köhler, 1987). Recently, further adjustments to the land cover have been made through management of the research garden and installation of a $40 \mathrm{~m}$ eddy flux tower as part of the Urban Climate Observatory (UCO) of the TU Chair of Climatology for long-term observations of atmospheric processes in cities (Fig. 1). The premises are now covered by buildings $(\sim 17 \%)$; different types of non-irrigated urban green spaces, including grassland $(\sim 16 \%)$, shrub $(\sim 7 \%)$ and trees $(\sim 39 \%)$; and semi-permeable or sealed pathways and parking spaces $(\sim 16 \%)$. Soils can be characterized as medium silty and loamy sands (SenStadtWoh, 2018). They reflect anthropogenic impacts, as the naturally occurring subglacial till is covered by $50-180 \mathrm{~cm}$ of debris, sandy materi- 


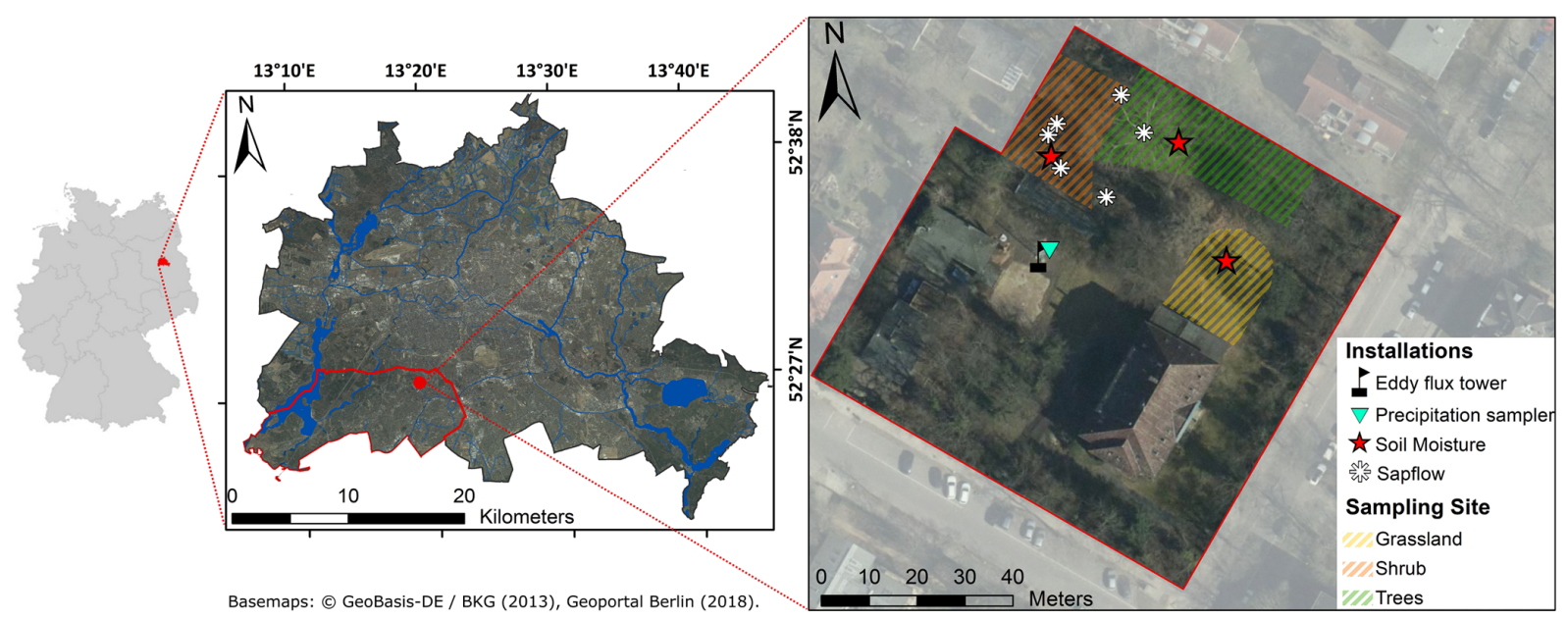

Figure 1. Location of Berlin within Germany (left); location of the district of Steglitz-Zehlendorf and the SUEO (red) with Berlin's surface waters in blue (middle); and the SUEO (right) with vegetation plots and installations of soil moisture and sap flow measurements, precipitation sampler and eddy flux tower.

als and a humus layer from long-term intensive cultivation and gardening (Bornkamm and Köhler, 1987).

\section{Methods and data}

Monitoring was carried out from March 2019 to March 2020, with particular focus on the growing season (April to October). Climate data were available from Berlin-Dahlem, $\sim 1500 \mathrm{~m}$ west of the site (precipitation $(P)$, air temperature $\left(T_{\text {air }}\right)$, relative humidity $(\mathrm{RH})$, vapour pressure; DWD, 2020a) and the TU UCO eddy flux tower (radiation fluxes, wind speed, ET estimates; Fig. 1). Groundwater-level data were available from the Berlin Senate (SenUVK, 2020).

Three generic urban vegetation types (grassland, shrub and trees) were selected as representative urban soil-vegetation plots (Fig. 1). Each plot was characterized by species typically found in more natural urban green spaces (e.g. parks; Table 1). The plots received no irrigation water throughout the study period. For soil moisture monitoring, CS650 reflectometers (Campbell Scientific, Inc.; accuracy $\pm 3 \%$ for volumetric water content, VWC) were installed at $10-15 \mathrm{~cm}$ $\left(\mathrm{VWC}_{12.5}\right), 40-50 \mathrm{~cm}\left(\mathrm{VWC}_{45}\right)$ and $90-100 \mathrm{~cm}\left(\mathrm{VWC}_{95}\right)$ in representative locations within each plot (Fig. 1), with duplicate sensors at each depth. Sensors were connected to CR300 data loggers in ENC8/10 enclosures (Campbell Scientific, Inc., Logan, USA). For sap flow, a FLGS-TDP XM1000 sap velocity logger system (Dynamax Inc, Houston, USA) measuring temperature differences between heated sensors (Granier, 1987) was installed at $1.5 \mathrm{~m}$ height within six representative urban trees (Fig. 1, Table 2). Dependent on tree height and age, two or four sets of sensors were installed in each cardinal direction, with more in older, larger trees. $P$ was sampled daily for isotope analysis using a 3700 sampler (Teledyne Isco, Lincoln, USA). To prevent evaporation,
Table 2. Characteristics of trees and sensors of the sap flow installation.

\begin{tabular}{lrrr}
\hline Tree species & $\begin{array}{r}\text { Diameter } \\
\text { at breast } \\
\text { height }(\mathrm{cm})\end{array}$ & $\begin{array}{r}\text { Number } \\
\text { of } \\
\text { sensors }\end{array}$ & $\begin{array}{r}\text { Sensor } \\
\text { type }\end{array}$ \\
\hline Maple (Acer platanoides, & 8.9 & 2 & TDP10 \\
Acer pseudoplatanus) & 10.5 & 2 & TDP30 \\
& 14.0 & 2 & TDP30 \\
\hline Elm (Ulmus glabra) & 18.5 & 2 & TDP30 \\
Plane (Platanus $x$ hybrida) & 111.4 & 4 & TDP30 \\
Oak (Quercus robur) & 67.8 & 4 & TDP50 \\
\hline
\end{tabular}

$1.5 \mathrm{~cm}$ of paraffin oil was added to each bottle, and occasional samples of $<1.5 \mathrm{~mm}$ were rejected in case of exaggerated fractionation effects. For soil water isotope sampling, eight monthly campaigns were conducted from AprilNovember 2019. In each campaign, samples were taken under grassland, shrubs and trees (Fig. 1). To cover potential heterogeneities at the site, three spatially distributed points were sampled respectively under each vegetation type. Duplicate soil cores were taken at 0-10, 10-20, 40-50 and 80$90 \mathrm{~cm}$ depth at each location using a soil auger. Samples of $\sim 250 \mathrm{~cm}^{3}$ volume were filled into bags (WEBAbag, Silver Range, Weber Packaging, Germany), immediately sealed, avoiding air inclusions, and stored in a thermally isolated box. Groundwater was sampled seasonally for isotope analysis from October 2018 to July 2019 across the whole city (Kuhlemann et al., 2020a), including an observation well $\sim 2.5 \mathrm{~km} \mathrm{NE}$ of the site, which was used in comparison to the SUEO samples for context.

Filtered $P$, groundwater and surface water samples were analysed by cavity ring-down spectroscopy with an L2130-i 
isotopic water analyser (Picarro, Inc., USA). Four lab standards were used for linear correction and standards of the International Atomic Energy Agency (IAEA) for calibration. Results were expressed in $\delta$ notation with Vienna Standard Mean Ocean Water (VSMOW). Mean analytical precision was $0.05 \%$ standard deviation (SD) for $\delta^{18} \mathrm{O}$ and $0.16 \%$ $\mathrm{SD}$ for $\delta \mathrm{D}$.

Soil samples were analysed using the direct equilibrium method (Wassenaar et al., 2008). First, additional bags were filled with $10 \mathrm{~mL}$ of three liquid lab standards (with duplicates). Second, all bags were inflated with dry air, welded, equipped with a silicon septum and stored for $\sim 48 \mathrm{~h}$ to equilibrate. Third, the vapour phase was analysed using the Picarro L2130-i by inserting a needle attached to a tube into the bags through the silicon. Standards were measured at the beginning, middle and end of each run. Criteria for plateau detection during analysis were $\mathrm{SD} \mathrm{H}_{2} \mathrm{O}<100 \mathrm{ppm}, \mathrm{SD} \delta^{18} \mathrm{O}<$ $0.35 \%$ and $\mathrm{SD} \delta \mathrm{D}<0.55 \%$. Analytical precision was mean SD of $0.14 \%$ and $0.34 \%$ for $\delta^{18} \mathrm{O}$ and $\delta \mathrm{D}$, respectively. Selected bags were remeasured after 2-4 weeks for gas matrix correction (Grahler et al., 2018). Samples were subsequently oven-dried at $105^{\circ} \mathrm{C}$ for $24 \mathrm{~h}$ and weighted to determine their gravimetric water content. Samples with $<3 \mathrm{~g}$ of water were excluded from analysis (Hendry et al., 2015).

For sap flow, individual sensor values for each tree were averaged, converted to sap flux velocity $(u)$ in millimetres per hour (mm/h) (Granier, 1987) and summed up to daily totals. Potential evapotranspiration (PET) was estimated using the FAO Penman-Monteith method (Allen et al., 1998). For a more generalized view on the dynamics during the growing season, both $u$ and PET were then normalized (to $u_{\text {norm }}$ and $\mathrm{PET}_{\text {norm }}$, respectively) by subtracting the mean over the study period from the individual daily values and dividing by SD.

At each site, VWC of duplicate sensors was averaged hourly. For the growing period, a mass balance approach was applied for a first approximation of ET. As the site topography was flat and the study period dry and consistent with the soil moisture data, we assumed no percolation below $50 \mathrm{~cm}$ and negligible lateral flow. At each site, daily storage change was calculated as $\Delta S=\mathrm{VWC}_{12.5} \cdot h_{12.5}+\mathrm{VWC}_{45} \cdot h_{45}$ with $h$ as depth of the soil layer. Daily ET was then estimated as $\operatorname{ET}_{\text {calc }}(\mathrm{mm})=\Delta S-P$. Occasional small negative daily

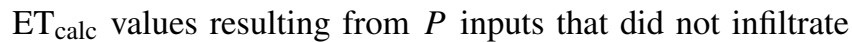
to sensors were assumed to be zero. Daily ET $_{\text {calc }}$ was then aggregated to weekly sums. The procedure was repeated for ET from the eddy flux tower at $30 \mathrm{~m}$ height. For comparison of accumulated ET, monthly $\mathrm{ET}_{\text {calc }}$ at the individual sites was summed over the growing period, and a weighted mean was calculated considering the fractional distribution of vegetation types at the site. Weekly means were computed for environmental variables $\left(\mathrm{VWC}_{12.5}\right.$; vapour pressure deficit (VPD $\left.{ }_{\text {air }}\right)$ calculated from $T_{\text {air }}$ and $\mathrm{RH}$; and net radiation $\left(R_{\mathrm{n}}\right)$ calculated from short- and longwave fluxes in $2 \mathrm{~m}$ height) to explore linear correlation with weekly $\mathrm{ET}_{\text {calc }}$ and $u_{\text {norm }}$.
From daily $P$ isotopes, a local meteoric water line (LMWL) was calculated by amount-weighted least square regression (Hughes and Crawford, 2012). For all isotope samples, deuterium (d-) excess was calculated as d-exc $=\delta \mathrm{D}-8 \cdot \delta^{18} \mathrm{O}$ (Dansgaard, 1964). To compare soil isotope data with depth, geometric means were calculated from plot and depth replicates. Mean values for soil profiles at the individual sites and sampling campaigns were compared to mean $\mathrm{ET}_{\text {calc }}, T_{\text {air }}$, $\mathrm{VPD}_{\text {air }}, R_{\mathrm{n}}$ and $P$ isotopes in the month before or weeks between each sampling campaign through linear regression. A mean value of seasonally sampled groundwater (Kuhlemann et al., 2020a) was calculated to compare to $P$ and soil water isotopes.

To obtain a first approximation of soil water ages at different sites and depths, stable isotopes of $P$ and soil water were used to calculate fractions of young water $\left(F_{\mathrm{yw}}\right)$ by sinewave fitting of seasonal cycles (von Freyberg et al., 2018). Strongly fractionated samples from the upper two soil layers were identified by comparing to incoming $P$ and excluded from analysis if the soil isotopic values were above the maximum $P$ isotopic value. Mean transit times (MTTs) were calculated by a lumped convolution method (McGuire and McDonnell, 2006). Amount-weighted weekly $P$ isotope means were used as input with a 1 -year spin-up period. Shape $(\alpha$, range $0.001-5)$ and scale $(\beta$, range $1-50)$ parameters were estimated for a gamma transfer function by maximizing the Kling-Gupta efficiency (KGE; Gupta et al., 2009) of estimated monthly soil isotopes to the measured monthly soil water isotope data.

\section{Results}

\subsection{Ecohydrological partitioning of water under different generic vegetation communities}

Monitoring followed the 2018 summer drought which affected much of central Europe (Buras et al., 2020) and below-average $P$ in the winter of $2018 / 2019$. Compared to the long-term mean (1981-2010; DWD, 2020b), 2018 was $+1.6^{\circ} \mathrm{C}$ warmer and had a $P$ deficit of $232 \mathrm{~mm}$ (or $39 \%$ ) in Berlin Dahlem (DWD, 2020a). At the start of the study from March-May, mean daily $T_{\text {air }}$ was $\sim 10^{\circ} \mathrm{C}$, and $P$ was low, at $\sim 15 \mathrm{~mm} /$ month (Fig. 2a, b). From mid-May to mid-June, $T_{\text {air }}$ increased to $\sim 18^{\circ} \mathrm{C}$, and several heavy convective $P$ events totalled $>100 \mathrm{~mm}$ (Table 3, Fig. 2a, b). Conditions remained warm and dry until late September, with most $P$ occurring in further high-intensity convective events (Table 3 , Fig. 2a, b). The remaining period until March 2020 was characterized by lower $T_{\text {air }}$ and more frequent, low-intensity $P$. Overall, 2019, similar to 2018, was warmer and drier than the long-term average, with a $P$ deficit of $85 \mathrm{~mm}(14 \%)$ and $T_{\text {air }}+1.7^{\circ} \mathrm{C}$ (DWD, 2020a, b).

Variable $T_{\text {air }}$ and $P$ during the study period inevitably impacted soil water storage. Under grassland, $\mathrm{VWC}_{12.5}$ de- 
Table 3. Climate parameters (DWD, 2020a) and VWC under the different vegetation units in the month before or weeks between the individual soil sampling campaigns.

\begin{tabular}{llrrrrrrrr}
\hline Sampling & & 1 (Apr) & 2 (May) & 3 (Jun) & 4 (Jul) & 5 (Aug1) & 6 (Aug2) & 7 (Sep) & 8 (Nov) \\
\hline Time period & & 16 March- & 16 April- & 15 May- & 12 June- & 3 July- & 5-28 & 28 August- & 25 September- \\
& & 16 April & 15 May & 12 June & 3 July & 5 August & August & 25 November & 27 November \\
\hline \multirow{2}{*}{$T_{\text {air }}\left({ }^{\circ} \mathrm{C}\right)$} & Mean & 8.12 & 11.70 & 17.96 & 21.50 & 19.35 & 20.09 & 17.65 & 9.25 \\
& SD & 3.12 & 3.13 & 4.13 & 3.31 & 3.28 & 2.46 & 4.00 & 4.22 \\
\hline$P(\mathrm{~mm})$ & Sum & 11.90 & 13.20 & 103.10 & 2.80 & 63.70 & 19.40 & 41.80 & 121.20 \\
\hline \multirow{2}{*}{ VWC grassland } & Mean & 24.30 & 18.34 & 16.50 & 19.16 & 15.35 & 14.46 & 12.98 & 20.28 \\
& SD & 1.27 & 1.38 & 1.56 & 2.51 & 1.62 & 1.27 & 1.60 & 2.37 \\
\cline { 2 - 9 } VWC shrub & Mean & 16.41 & 13.89 & 12.90 & 12.33 & 9.24 & 8.51 & 8.27 & 12.20 \\
& SD & 0.55 & 0.74 & 1.58 & 2.21 & 0.61 & 0.37 & 0.45 & 1.19 \\
\cline { 2 - 9 } VWC trees & Mean & 20.14 & 15.30 & 12.57 & 11.74 & 9.78 & 9.12 & 8.98 & 11.71 \\
& SD & 0.50 & 1.80 & 1.64 & 1.95 & 0.91 & 0.40 & 0.55 & 1.18 \\
\hline
\end{tabular}

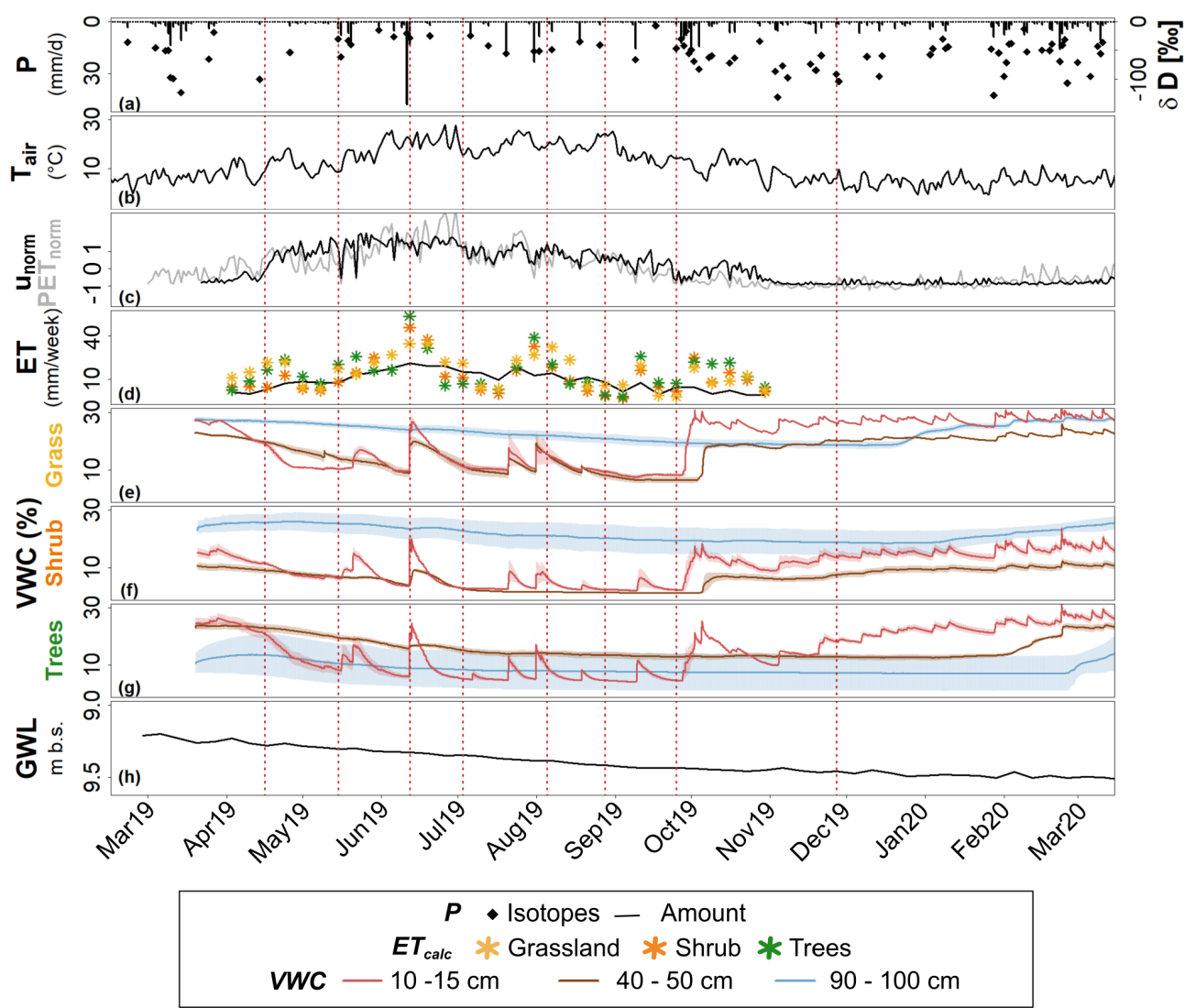

Figure 2. (a) Daily $P$ sums (DWD, 2020a) and isotopic composition, (b) mean daily $T_{\text {air }}$ (DWD, 2020a), (c) daily $u_{\text {norm }}$ and PET norm (grey) (d) weekly $\mathrm{ET}_{\text {calc }}$ and ET of the eddy flux tower (grey line), (e-g) soil VWC at different depths and sites and (h) mean weekly groundwater level (GWL) near the SUEO (SenUVK, 2020). Dashed red lines mark the days on which soil samples were taken for monthly soil water isotope analysis. 

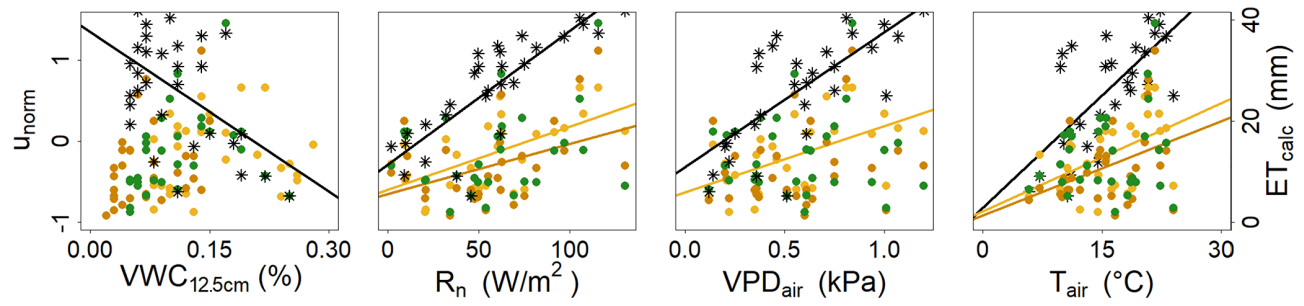

Figure 3. Linear correlation of hydroclimatic variables $\left(\mathrm{VWC}_{12.5}, R_{\mathrm{n}}, \mathrm{VPD}_{\text {air }}, T_{\text {air }}\right)$ with measured weekly $u_{\text {norm }}$ at the tree site (asterisk) and calculated weekly $\mathrm{ET}_{\text {calc }}$ at the grassland (yellow), shrub (orange) and tree (green) sites.

Table 4. Accumulated $\mathrm{ET}_{\text {calc }}$ over the growing period of 2019.

\begin{tabular}{lrrr}
\hline & \multicolumn{3}{c}{$\mathrm{ET}_{\text {calc }}(\mathrm{mm})$} \\
\cline { 2 - 4 } & Grassland & Shrub & Trees \\
\hline April & 62.00 & 33.82 & 51.76 \\
May & 112.81 & 80.18 & 116.25 \\
June & 209.16 & 171.21 & 203.51 \\
July & 262.58 & 216.60 & 244.16 \\
August & 335.26 & 261.36 & 305.78 \\
September & 364.32 & 288.11 & 345.08 \\
October & 413.60 & 343.92 & 415.59 \\
\hline
\end{tabular}

creased to $<10 \%$ during summer, with transient increases after $P$ (Fig. 2e). Prolonged re-wetting in October returned VWC $_{12.5}$ to March 2019 levels, with minor variability thereafter. At the other sites (Fig. 2f, g), VWC 12.5 was lower generally, decreasing during dry periods to $\sim 2 \%$ in June/July (shrub) and $\sim 4 \%$ in September (trees). Wetness increased again over the winter. At all sites, $\mathrm{VWC}_{12.5}$ of duplicate sensors was in a similar range. $\mathrm{VWC}_{45}$ dynamics were "damped" in comparison. Under grassland, $\mathrm{VWC}_{45}$ declined over summer to $<10 \%$ from May onwards, until increasing again a few days later than the shallower soil in October (Fig. 2e). Under shrub, patterns were similar (Fig. 2f). Under trees, $\mathrm{VWC}_{45}$ slowly declined to $\sim 15 \%$ throughout the summer, with no marked response to any $P$. It only started to increase again in February 2020 (Fig. 2g). Temporal variations in $\mathrm{VWC}_{95}$ were lowest. Values continuously declined over summer, with no response to $P$. Under grassland and shrub, $\mathrm{VWC}_{95}$ was higher than at shallower depths for most of the growing period (Fig. 2e, f). Under trees, VWC 95 was lower, with a high discrepancy between duplicate sensors (Fig. 2g). VWC95 only started to increase again in January (grassland, shrub) and March 2020 (trees). Despite some variation, the groundwater level in the closest well $(500 \mathrm{~m}$ SE of the SUEO) continuously declined from 9.2 to $9.5 \mathrm{mb}$.s. (Fig. 2h), suggesting no net recharge during the study period.

Daily $u_{\text {norm }}$ (Fig. 2c) showed a marked increase following the start of the growing season in April 2019 as trees came into leave. Values were highest from May-July, with daily variability and negative troughs coinciding with larger
$P$ events. From August-October, variability remained, but $u_{\text {norm }}$ decreased, with short-term decreases around $P$ events. After slight variability in October, rates permanently decreased after leaf fall. PET $_{\text {norm }}$ (Fig. 2c) showed similar seasonality, with the highest rates in June-July. However, during some of the highest PET $_{\text {norm }}$ increases, $u_{\text {norm }}$ did not respond.

Weekly $\mathrm{ET}_{\text {calc }}$ ranged from $<5 \mathrm{~mm} /$ week under dry, cool conditions to $\sim 40 \mathrm{~mm} /$ week after heavy $P$ events (Fig. $2 \mathrm{~d}$ ). At the start of the growing period in April, $\mathrm{ET}_{\text {calc }}$ was highest in grassland, but after leaf-out, the tree site was higher for some weeks in May and June. Increases in $\mathrm{ET}_{\text {calc }}$ after large $P$ events were especially pronounced at the tree site, while grassland $\mathrm{ET}_{\text {calc }}$ remained highest during dry periods in July and August (Fig. 2d). Shrub patterns were variable, with $\mathrm{ET}_{\text {calc }}$ lowest at the start of the growing season and from July to October but intermediate from May to July and October and in response to $P$ events (Fig. 2d). Accumulated $\mathrm{ET}_{\text {calc }}$ by October was similar $(\sim 415 \mathrm{~mm})$ at the grassland and tree sites but lower at the shrub site $(344 \mathrm{~mm}$; Table 4$)$. $\mathrm{ET}_{\text {calc }}$ variations roughly resembled the dynamics measured by the eddy flux tower, although those were more damped (Fig. 2d) and totaled only $285 \mathrm{~mm}$ over the same time period. Area-weighted summertime (May-October) $\mathrm{ET}_{\text {calc }}$ for the vegetation community was $351 \mathrm{~mm}$.

The highest correlations with environmental variables (Fig. 3, Table 5) were observed between $u_{\text {norm }}$ and $R_{\mathrm{n}}$ and less strongly between $u_{\text {norm }}$ and $\mathrm{VWC}_{12.5}, \mathrm{VPD}_{\text {air }}$ and $T_{\text {air }}$. Correlation between $u_{\text {norm }}$ and $\mathrm{VWC}_{12.5}$ was negative, while all others were positive. Significant positive correlations were also observed between grassland $\mathrm{ET}_{\text {calc }}$ and $R_{\mathrm{n}}$, $\mathrm{VPD}_{\text {air }}$ and $T_{\text {air }}$. Correlations with $\mathrm{ET}_{\text {calc }}$ at the shrub and tree sites were low.

\subsection{Ecohydrological partitioning under different urban soil-vegetation units inferred from the isotopic composition of precipitation and soil water}

$P$ isotopes were generally depleted in winter and more enriched in summer. The range was $-17.3 \%$ to $-0.3 \%$ for $\delta^{18} \mathrm{O},-131.3 \%$ to $-12.7 \%$ for $\delta \mathrm{D}$ and $-10.4 \%$ to $15.7 \%$ for d-excess (Fig. 2a). The amount-weighted LMWL during 
Table 5. $R^{2}$ and $p$ values of the parameters used for the correlation plots of $u_{\text {norm }}$ and $\mathrm{ET}_{\text {calc }}$ (Fig. 3).

\begin{tabular}{|c|c|c|c|c|c|c|c|c|c|}
\hline & & \multicolumn{2}{|c|}{$\mathrm{VWC}_{12.5}$} & \multicolumn{2}{|r|}{$T_{\text {air }}$} & \multicolumn{2}{|c|}{$\mathrm{VPD}_{\text {air }}$} & \multicolumn{2}{|r|}{$R_{\mathrm{n}}$} \\
\hline & & $R^{2}$ & $p$ value & $R^{2}$ & $p$ value & $R^{2}$ & $p$ value & $R^{2}$ & $p$ value \\
\hline$u_{\text {norm }}$ & & 0.27 & $3.00 \times 10^{-3}$ & 0.44 & $4.56 \times 10^{-5}$ & 0.49 & $1.33 \times 10^{-5}$ & 0.71 & $2.49 \times 10^{-9}$ \\
\hline \multirow{3}{*}{$\mathrm{ET}_{\text {calc }}$} & Grassland & 0.01 & 0.54 & 0.25 & $4.06 \times 10^{-3}$ & 0.29 & $1.70 \times 10^{-3}$ & 0.39 & $1.70 \times 10^{-4}$ \\
\hline & Shrub & 0.10 & 0.08 & 0.16 & 0.03 & 0.05 & 0.23 & 0.20 & 0.01 \\
\hline & Trees & 0.10 & 0.08 & 0.05 & 0.24 & $1.00 \times 10-3$ & 0.86 & 0.09 & 0.10 \\
\hline
\end{tabular}

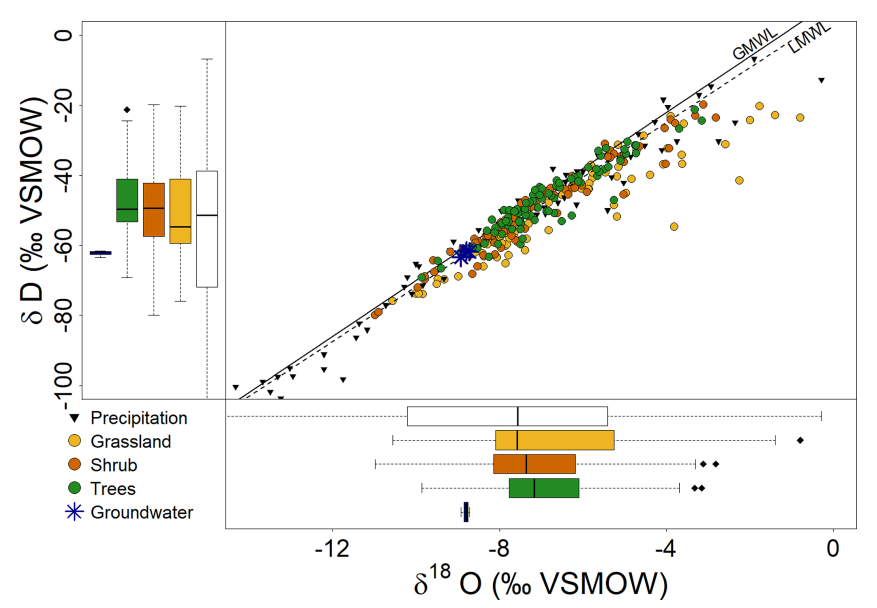

Figure 4. Dual isotope and box plots showing the isotopic composition of incoming $P$ and local groundwater sampled $\sim 2.5 \mathrm{~km}$ north of the SUEO (Kuhlemann et al., 2020a), as well as the isotopic composition of sampled bulk soil water at different depths between 0 and $90 \mathrm{~cm}$ under grassland, shrub and tree sites.

our sampling period (Fig. 4) was $\delta \mathrm{D}=7.82 \pm 0.26 \cdot \delta^{18} \mathrm{O}+$ $6.31 \pm 1.25\left(R^{2}=0.974\right)$.

Soil water samples under grassland showed the widest range for $\delta^{18} \mathrm{O}$, and some surface layer samples deviated substantially from the global meteoric water line (GMWL) and LMWL (Fig. 4). However, across the entire soil profile (0$90 \mathrm{~cm}$ ), isotopes were least variable and more enriched under trees. Local groundwater was generally more depleted, while most soil water samples were more enriched and plotted further up the GMWL and LMWL.

Soil water isotopic composition generally became more depleted with depth (Table 6). Shallow soil layers under grassland were more enriched compared to shrub and trees, while the deeper soil layers were most enriched beneath trees. Mean negative d-excess, indicating evaporative losses (Dansgaard, 1964), was observed in the upper soil under grassland (Table 6), where $R_{\mathrm{n}}$ and $T_{\text {air }}$ significantly influenced the ET rates (Fig. 3, Table 5), but not under shrub and trees, where d-excess remained positive.

Soil water isotopes also showed strong temporal variation. In mid-April, when $P$ was low but the soils still wet (Fig. 2), values were depleted, especially under shrub. Values resembled the isotopic signal of incoming $P$ at $0-10 \mathrm{~cm}$, while values at $10-20 \mathrm{~cm}$ were even more depleted (Figs. 5, 6). D-excess was more negative at the grassland site, coinciding with higher $\mathrm{ET}_{\text {calc }}$ (Fig. 2d). Following little $P$ and increasing $T_{\text {air }}$ and $u_{\text {norm }}$, VWC had decreased by May (Fig. 2), and soil water became more enriched, especially at $0-10 \mathrm{~cm}$, while d-excess decreased throughout the profile, especially under grassland (Figs. 5, 6). While $T_{\text {air }}$ and $u_{\text {norm }}$ remained high over summer, the large convective $P$ event preceding the June sampling led to higher VWC and $\mathrm{ET}_{\text {calc }}$, especially at the tree site (Fig. 2), and a more enriched isotopic composition at $0-20 \mathrm{~cm}$. D-excess, however, became more positive in the shallow soil at all sites, overprinting previous signals of fractionation and displacing waters with lower d-excess to depth (Figs. 5, 6).

Through the warm, dry July-September period, VWC remained low (Fig. 2), and the isotopic composition of the shallow soil remained enriched but became depleted with depth (Figs. 5, 6). D-excess in the shallow soil was strongly negative at the grassland (Figs. 5, 6), where $\mathrm{ET}_{\text {calc }}$ was slightly higher (Fig. 2d). $P$ events in August temporarily increased VWC (Fig. 2e-g) and slightly moderated the fractionation effects (Figs. 5, 6). Importantly, it is notable from Fig. 6 that from April to July, the isotopic signature of the shallow soil $(0-10 \mathrm{~cm})$ always moved in the direction of incoming $P$ in the weeks preceding the respective samplings. From August to September, however, the isotopic composition of the shallow soil became increasingly more enriched than the incoming $P$, especially under grassland (Fig. 6). After $T_{\text {air }}, u_{\text {norm }}$ and $\mathrm{ET}_{\text {calc }}$ decreased and more frequent $P$ started in October (Fig. 2), soil water isotopes in November were more depleted. However, the deeper soil, especially at $40-50 \mathrm{~cm}$, remained more enriched (Figs. 5, 6). Correlations between mean monthly $\delta^{18} \mathrm{O}$ and $\delta \mathrm{D}$ of the soil profiles and selected environmental variables in the month before or weeks between the samplings are shown in Fig. 7 and Table 7. Under grassland, soil isotopes showed a strong positive correlation with $T_{\text {air }}$ and a weaker one with $\mathrm{VPD}_{\text {air }}$. Under trees, soil isotopes showed significant positive correlations with $R_{\mathrm{n}}$, $\mathrm{VPD}_{\text {air }}, T_{\text {air }}$ and incoming $P$ isotopes. Under shrub, correlations were weaker; only a positive correlation with $T_{\text {air }}$ was evident. 

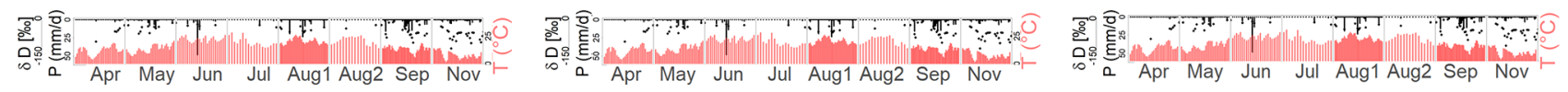

Grassland

Shrub

\section{Trees}
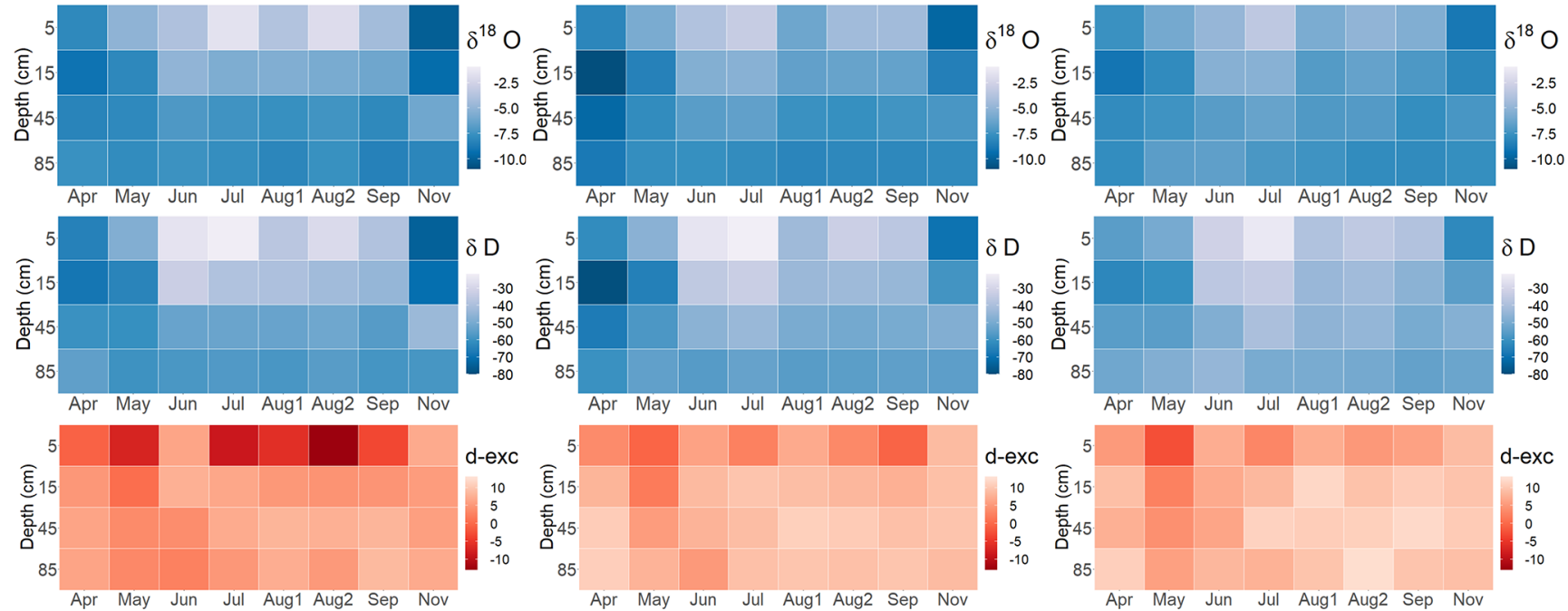

Figure 5. Heat maps showing the isotopic composition of the different soil layers during the monthly sampling campaigns (for abbreviations, see Table 3) in \%o VSMOW. Climate parameters (top; DWD, 2020a) mark the daily $T_{\text {air }}$ and $P$ during the sampling period.
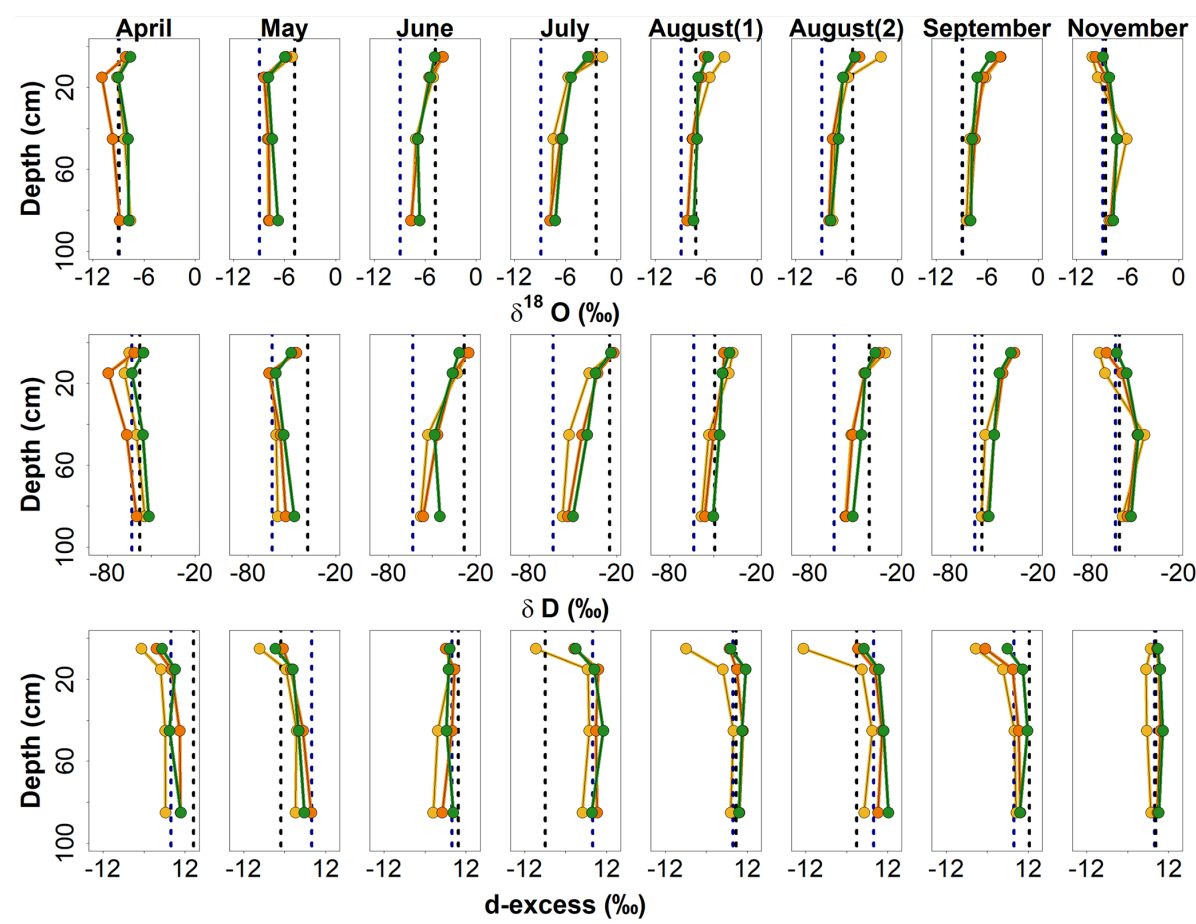

Figure 6. Isotopic depth profiles showing geometric means at different depths at the grassland (yellow), shrub (orange) and tree sites (green) during the monthly sampling campaigns. Dashed lines marking the mean isotopic composition of groundwater (blue) and weighted $P$ mean in the month before or weeks between the sampling campaigns are given for reference. 
Table 6. Number of samples $(n)$ with measured isotopic composition of $P$ and soil water under the three soil-vegetation units for different sampling depths.

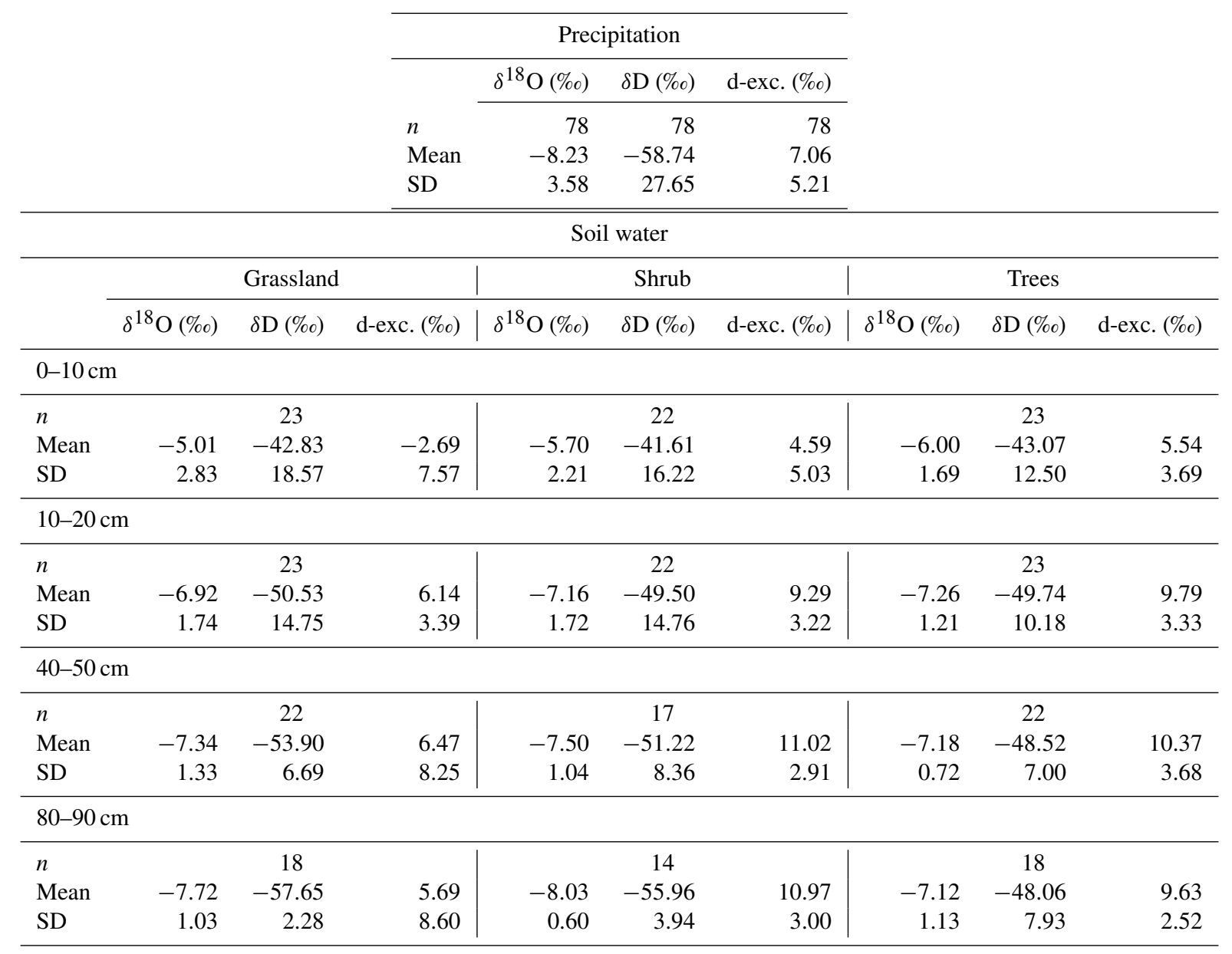

\subsection{Water ages and travel times of water in the unsaturated zone under different urban vegetation units}

Estimated $F_{\mathrm{yw}}$ values of soil water at the different sites and depths indicate that under grassland, where isotopes and dexcess suggested highest evaporative losses over the summer (Figs. 5, 6), the shallow soil was dominated by young water $<8$ weeks old (Fig. 8). MTTs were $<6$ weeks in the upper $20 \mathrm{~cm}$, with a good KGE fit (0.39-0.93; Fig. 8). A similar pattern was estimated for shrub. Under trees, where $\mathrm{VWC}_{12.5}$ was low (Fig. $2 \mathrm{~g}$ ) and isotopes indicated less pronounced evaporative enrichment (Figs. 5, 6), older water contributed $\sim 35 \%$ in $10-20 \mathrm{~cm}$ depth. MTTs of $<8.3$ weeks (KGE fit $0.71-0.94$ ) in the upper $20 \mathrm{~cm}$ were slightly higher than under grassland and shrub. In the mid-profile at 40 $50 \mathrm{~cm}$ depth, $F_{\mathrm{yw}}$ remained high $(>70 \%)$ under shrub, where $\mathrm{VWC}_{45}$ was lowest (Fig. 2f), while only 20\%-33\% of young water could be observed under grassland and trees (Fig. 8). Similarly, MTTs were lower under shrub (17-18 weeks, KGE fit $\sim 0.81$ ) than under grassland (23-29 weeks,
KGE fit 0.44-0.62) and trees (21 to 40 weeks, KGE fit 0.62$0.80)$. In $80-90 \mathrm{~cm}, F_{\mathrm{yw}}$ was low, especially under grassland (5\%-11\%; Fig. 8) where $\mathrm{VWC}_{95}$ was higher (Fig. 2e), but also at the drier shrub and tree sites (11\%-18\%). MTTs were substantially longer than at shallower depths, especially under trees (50-59 weeks) and shrub (49-62 weeks). Due to the lack of variability and the limited observation period, estimates at depth were more uncertain, with a KGE fit of 0.130.54 at all sites.

\section{Discussion}

\subsection{Quantitative assessment of ecohydrological partitioning under different urban soil-vegetation units}

Through our integrated plot-scale study during and after the exceptional summers of 2018 and 2019, we gained novel insights into ecohydrological partitioning in urban green 

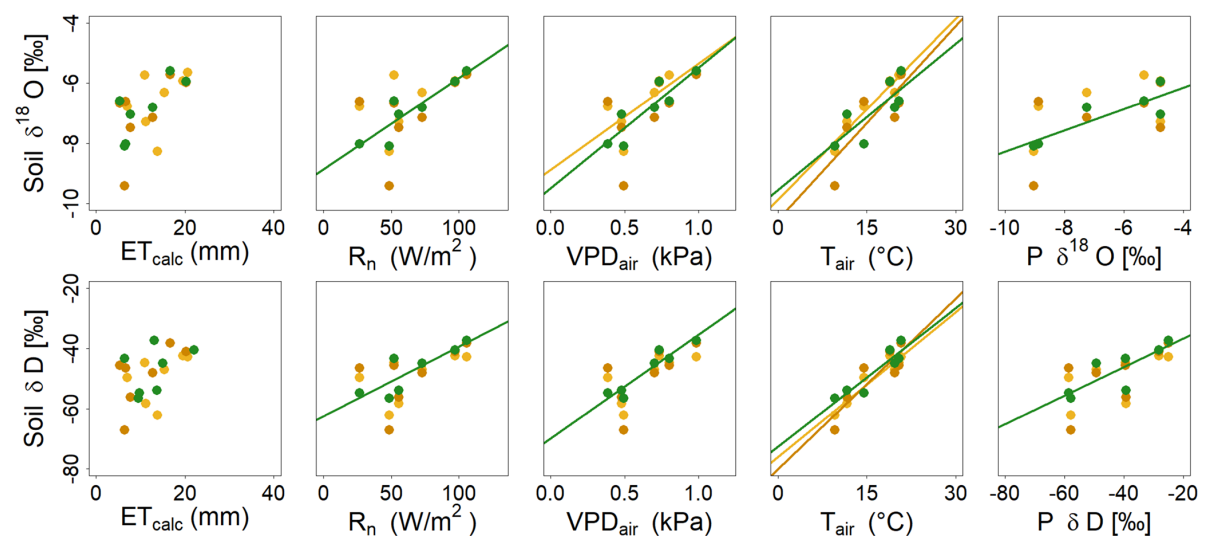

Figure 7. Linear correlations at the grassland (yellow), shrub (orange) and tree sites (green) between mean analysed soil water isotopic composition on the individual sampling dates and mean values of environmental parameters in the month before or weeks between the respective samplings.

Table 7. Correlations between analysed soil water isotopic composition and mean environmental variables $\sim 4$ weeks prior to the sampling (Fig. 7).

\begin{tabular}{|c|c|c|c|c|c|c|c|c|c|c|c|}
\hline & & \multicolumn{2}{|c|}{$\mathrm{ET}_{\text {calc }}$} & \multicolumn{2}{|r|}{$T_{\text {air }}$} & \multicolumn{2}{|c|}{$\mathrm{VPD}_{\text {air }}$} & \multicolumn{2}{|r|}{$R_{\mathrm{n}}$} & \multicolumn{2}{|c|}{$P$ isotopes } \\
\hline & & $R^{2}$ & $p$ value & $R^{2}$ & $p$ value & $R^{2}$ & $p$ value & $R^{2}$ & $p$ value & $R^{2}$ & $p$ value \\
\hline \multirow{3}{*}{$\delta^{18} \mathrm{O}$} & Grassland & 0.15 & 0.38 & 0.93 & $5 \times 10^{-4}$ & 0.60 & 0.04 & 0.32 & 0.18 & 0.44 & 0.10 \\
\hline & Shrub & 0.35 & 0.16 & 0.65 & 0.03 & 0.35 & 0.16 & 0.28 & 0.22 & 0.45 & 0.10 \\
\hline & Trees & 0.26 & 0.24 & 0.62 & 0.04 & 0.79 & $7 \times 10^{-3}$ & 0.81 & $6 \times 10^{-3}$ & 0.85 & $4 \times 10^{-3}$ \\
\hline \multirow{3}{*}{$\delta \mathrm{D}$} & Grassland & 0.19 & 0.32 & 0.91 & $8 \times 10^{-4}$ & 0.54 & 0.06 & 0.33 & 0.17 & 0.38 & 0.14 \\
\hline & Shrub & 0.38 & 0.14 & 0.78 & $8 \times 10^{-3}$ & 0.44 & 0.10 & 0.31 & 0.19 & 0.44 & 0.11 \\
\hline & Trees & 0.17 & 0.37 & 0.85 & $3 \times 10^{-3}$ & 0.89 & $1 \times 10^{-3}$ & 0.72 & 0.02 & 0.68 & 0.02 \\
\hline
\end{tabular}

spaces under dry, warm conditions which will likely become more common in future.

Firstly, by combining sap flow measurements with soil moisture and climate data, we were able to gain some first insights into the response of non-irrigated urban trees to these conditions. The observed dependence of seasonal $u_{\text {norm }}$ (as a proxy for transpiration) on $R_{\mathrm{n}}, \mathrm{VPD}_{\text {air }}$ and $T_{\text {air }}$ is in agreement with previous observations in urban trees that showed temporal sap flux variability is largely driven by variations in vapour pressure deficit and photosynthetically active radiation (Asawa et al., 2017; Pataki et al., 2011b). Though some larger $P$ events temporarily increased VWC, the simultaneous increase in $\mathrm{RH}$ and decrease in $R_{\mathrm{n}}$ and $\mathrm{VPD}_{\text {air }}$ caused the transpiration rates to temporarily decrease, explaining negative troughs and correlation. Such low dependency of transpiration rates on soil water content, despite limited $P$, is in contrast to low-energy headwater catchments (Wang et al., 2017). This may indicate that transpiration rates at our site showed a certain resilience against prolonged drought periods and depletion of soil moisture, which would coincide with a rural study east of Berlin following the 2018 drought (Kleine et al., 2020). However, decreased $u_{\text {norm }}$ during times of highest $\mathrm{PET}_{\text {norm }}$ would be consistent with the trees con- serving water resulting from moisture stress from the dry subsoil. This may at least in part also explain the ET losses under trees being less than the grassland, if low soil moisture limits ET. This may also be the result of "memory effects", i.e. the depletion of soil storage, after the extreme drying in summer 2018 and lower than average re-wetting in the following winter. In addition, the delivery of rainfall in intense convectional events may limit the time the canopy is wet, with low radiation and high humidity at such times limiting interception losses compared to more upland, windy sites (e.g. Soulsby et al., 2017). By selecting a mixed urban tree assemblage of different tree ages and species, our approach likely captures the heterogeneity in urban green spaces (cf. Nouri et al., 2013).

Secondly, the quantitative assessment of urban ET patterns under a mosaic of green spaces, a key challenge in urban ecohydrology (e.g. Nouri et al., 2013; Pataki et al., 2011a, b), showed that "green water" fluxes in the growing period increased in the order shrub $<$ grassland $\cong$ trees. These differences in ecohydrological partitioning under contrasting urban vegetation types during the 2019 growing season were in some ways counter-intuitive. At the grassland site, shading from surrounding trees was limited and the soil was only 


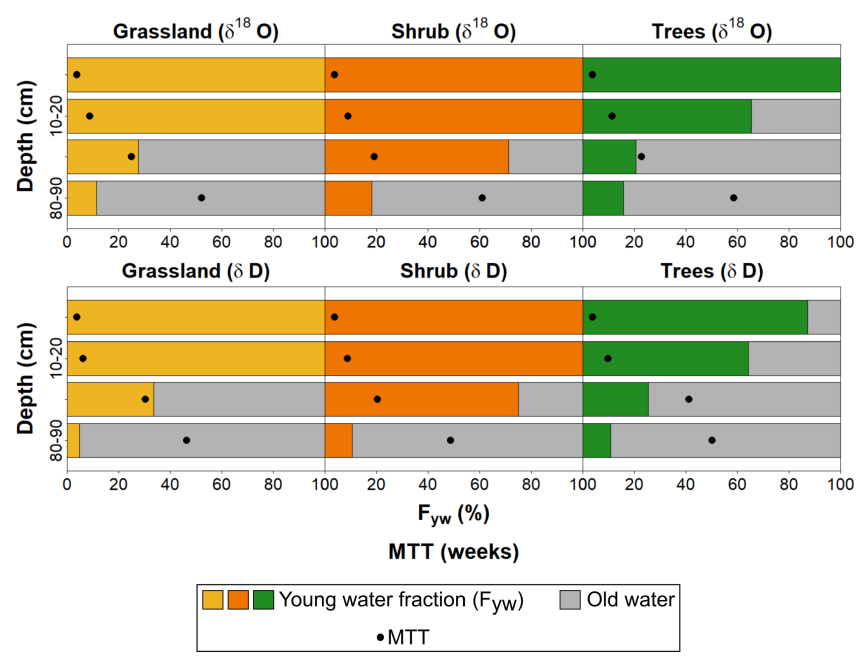

Figure 8. $F_{\mathrm{yw}}$ and MTTs at different sites and depths $(0-10 \mathrm{~cm}$, $10-20 \mathrm{~cm}, 40-50 \mathrm{~cm}$ and $80-90 \mathrm{~cm}$ ) during the growing period of 2019.

covered by the grass sward and patchy moss ground level. Consequently, with limited interception, incoming $P$ could directly infiltrate and drive the rapid soil moisture dynamics whilst simultaneously sustaining transpiration. Similarly, the sparse soil cover enhanced atmospheric exposure for evaporation at the soil surface when $T_{\mathrm{air}}, R_{\mathrm{n}}$ and $\mathrm{VPD}_{\text {air }}$ were high. In contrast, at the tree site, soil was covered by a ground layer of ivy and leaf litter and shaded by an almost-closed canopy during the growing season. It is likely that much higher interception losses and transpiration by trees and the understorey, the latter reflected by $u_{\text {norm }}$, contributed to higher ET rates at this site, leading to drier soils, less responsiveness to $P$ and longer time lags until re-wetting of the deeper soil in autumn. Inter-sensor variation of $\mathrm{VWC}_{95}$ under trees likely reflects heterogeneity in subsurface texture, as intercalations of sandy and loamy materials were present throughout the site. Over most of the study period, the shrub site exhibited intermediate hydrological responses to grassland and trees, e.g. regarding VWC and $\mathrm{ET}_{\text {calc }}$. However, accumulated ET losses were lowest. This may imply that more water reached the soil under shrub than under trees, as interception and transpiration losses from shrubs with a more open canopy and shallower rooting were lower. At the same time, less water directly re-evaporated from the surface than at the grassland site, as some soil cover of ivy and leaf litter was present. The area-weighted, accumulated summertime $\mathrm{ET}_{\text {calc }}$ for the mixed urban vegetation community at our site was $351 \mathrm{~mm}$. Thereby, it exceeded the sum of incoming $P$ (308 mm, DWD, 2020a) but remained lower than summertime PET $(360 \mathrm{~mm})$ and the annual average area-weighted ET estimates of $367 \mathrm{~mm} / \mathrm{yr}$ ( $60 \%$ of $P$ ) for the whole city of Berlin (SenStadtWoh, 2019).

However, these findings need to be interpreted cautiously as our simple approach to estimating ET through a plot-scale water balance may not fully account for spatial heterogeneity in soil moisture distribution and have uncertainties in accounting for deep percolation or capillary rise (Nouri et al., 2013). Nevertheless, the general similarity of $\mathrm{ET}_{\text {calc }}$ dynamics to values independently measured by the eddy flux tower indicates that it provided a reasonable first approximation. Higher green space $\mathrm{ET}_{\text {calc }}$ than the flux tower's estimates was expected, as the tower's $30 \mathrm{~m}$ height integrates a wider footprint of mixed urban (impermeable) surfaces that can increase surface runoff and decrease ET (e.g. Endreny, 2005; Fletcher et al., 2013; Schirmer et al., 2013).

\subsection{Isotopic composition of precipitation and soil water and its indications for ecohydrological partitioning under different urban vegetation types}

The LMWL of Berlin-Steglitz was close to the LMWLs previously reported for Germany and Berlin (Stumpp et al., 2014). The measured soil water isotopic composition largely supports inference from the hydrometric measurements but provides more nuanced insights into sources, movement and mixing of stored waters. Over the growing season, changes in soil water isotopes with depth reflected the general pattern of infiltrating $P$ becoming more enriched after evaporative losses in the upper $30 \mathrm{~cm}$ of soil, while the fractionation signal diminishes with depth as infiltrating $P$ mixes with soil waters, damping seasonal variability (Sprenger et al., 2016). The most pronounced isotopic enrichment and negative dexcess under grassland support a pattern of higher soil evaporative losses.

In April and May, more depleted values at 10-20 cm depth at all sites would be consistent with stored water from winter $P$ prior to sampling. In contrast, the negative d-excess in the upper $10 \mathrm{~cm}$ already indicates the effect of evaporative fractionation (Sprenger et al., 2019a). Subsequent incoming $P$ and soil evaporation, especially at the grassland site, strongly influenced the isotopic signal from May to July, though soil water in the upper 10 or even $20 \mathrm{~cm}$ was persistently more enriched than incoming $P$ in the second half of the growing season. This indicates that by August, despite temporary re-wetting by some larger $P$ events, insufficient $P$ infiltrated for the soil water to reflect its isotopic signature. This complements recent work in an irrigated urban forest in the western USA, which showed that towards the end of the growing season, even irrigation was insufficient to replenish soil water storage, and trees "switched" to using deeper, older soil waters (Gómez-Navarro et al., 2019). Though the isotopic composition of deeper soil layers moved in the direction of groundwater, the high depth of the groundwater table makes any influence through hydraulic redistribution, as recently observed by Oerter and Bowen (2019), unlikely, though a contribution of deeper soil water or groundwater through deep root water uptake from larger trees cannot be ruled out. By the end of November, the more enriched waters had percolated to $40-50 \mathrm{~cm}$ depth, but both $\mathrm{VWC}_{95}$ and the 
more enriched isotopic signature in $80-90 \mathrm{~cm}$ demonstrate that infiltrating water still had not reached this depth, despite more frequent $P$ from early October.

The overall more enriched isotopic composition of soil water under trees might point towards a contribution of more enriched throughfall (cf. Geris et al., 2015; Sprenger et al., 2017). However, d-excess remained high throughout the profile, and values were only more enriched compared to the other sites in the deeper $40-90 \mathrm{~cm}$, implying no percolation of more fractionated waters. Rather, there seems to be a "mismatch" between soil water in the upper 0-20 cm and soil water in the deeper $40-90 \mathrm{~cm}$ under trees. Stronger correlation between the isotopic composition of incoming $P$ and soil water under trees, along with higher d-excess, indicate that canopy and soil cover may preserve the infiltrating $P$ signal from direct re-evaporation. Therefore, despite lower net precipitation, the isotopic composition of soil water under trees was most strongly influenced by the isotopic signal of incoming $P$ and limited evaporation losses. Assuming that after the dry summer of 2018 percolation to $40-90 \mathrm{~cm}$ was similarly late as it was after 2019, when VWC only started to increase again towards spring 2020, the more enriched values at depth may be explained by a "memory effect" of recharge from the summer of 2018 under trees, while more infiltrating water over the winter had already replaced or mixed with this water at the grassland and shrub sites. This would be consistent with recent observations of decoupled hydrological systems by an in situ study in an irrigated urban landscape garden, where evaporation and irrigation determined highly variable seasonal isotope patterns in the upper $15 \mathrm{~cm}$ of soil, while the soil below $20 \mathrm{~cm}$ was only hydraulically connected to the shallow soil during wetter periods (Oerter and Bowen, 2017). Although a similar study in the rural east of Berlin did not observe a strong memory effect after the 2018 drought as a result of rapid mixing with new rainfall, there was some evidence for the displacement of non-evaporated, more enriched waters from summer to greater depth over the winter of 2018/2019 (Kleine et al., 2020).

\subsection{Preliminary assessment of water ages and travel times of water in the unsaturated zone under different urban vegetation types}

Higher soil evaporation and shallow root water uptake under grassland and shrub likely contributed to the predominance of young water and low MTT estimates for water stored at $0-20 \mathrm{~cm}$. Greater contributions of older water and slightly higher MTT under trees strengthen the hypothesis of longer turnover through interception losses and vegetation water use. The shrub site now shows a distinct pattern, with a higher fraction of young water with lower MTT stored at $40-50 \mathrm{~cm}$. Though this likely reflects a combination of lower interception and less direct evaporation, causing more young water to percolate to this depth, the low $\mathrm{VWC}_{45}$ does not fully support this. $F_{\mathrm{yw}}$ predicted at $80-90 \mathrm{~cm}$ was low; and indeed hydrometric data suggest that this would be associated with recharge in winter. It is likely that deeper roots under trees and shallower roots under shrub mostly take up older water, thereby increasing the influence of young waters and replenishing VWCs in autumn and winter, a pattern previously observed in non-irrigated, rural areas east of Berlin by Smith et al. (2020). Contributions of older waters, i.e. previous winter recharge to midsummer transpiration, were also observed in trees across Switzerland (Allen et al., 2019) and in soil and stem waters of irrigated urban forests in the western USA (Gómez-Navarro et al., 2019).

While hydrometric patterns were in agreement with previous studies in rural catchments of NE Germany, estimated MTT and $F_{\mathrm{yw}}$ were not always consistent. Though Douinot et al. (2019) found higher and younger recharge under grass than under trees, the differences were much greater over a 10 -year period. This may link to the greater longevity of that analysis period and resulting lower uncertainty of age estimates. Similarly, Kleine et al. (2020) and Smith et al. (2020) independently reported older water under grassland than under trees. However, this was primarily linked to more silty, water retentive soils under grassland, while soil properties were more consistent between sites in our study.

\subsection{Wider implications}

Many previous studies on urban vegetation have been conducted in semi-arid areas where urban green space is irrigated (e.g. Gómez-Navarro et al., 2019; Oerter and Bowen, 2017; Pataki et al., 2011b; Nouri et al., 2019). The absence of irrigation in our current study provided an opportunity to observe more "natural" vegetation water demands and ecohydrological partitioning. Additionally, drought responses of urban vegetation have not been well studied yet, but they can have major negative impacts on urban ecosystem services (Miller et al., 2020). As our study was carried out following the warmest year in German recorded history (Friedrich and Kasper, 2019), a relatively dry winter and consecutive dry summer with heavy convective $P$ events, it provides a first assessment on how such "natural" urban green spaces may react to increasingly warm and dry conditions. Understanding the water demands of different urban vegetation types during such conditions in non-irrigated state provides the basis for designing sustainable water management strategies in the future. Although urban vegetation in more temperate regions is usually not heavily irrigated, the increasing occurrence of warm and dry summers like in 2018 and 2019 may indicate that this will change in the future and that such strategies will become increasingly important.

Though urban forests can provide enhanced cooling benefits (e.g. Gunawardena et al., 2017), recent studies showed increasing emission of latent heat in grassland rather than forest during drought conditions in Europe (Lansu et al., 2020). While such large-scale findings may not be easily transferable to the plot scale, urban site, isotope tracers in our 
study revealed higher soil evaporation under urban grassland, though tree transpiration and interception lead to similarly high ET rates over the growing season. However, pronounced depletion of soil moisture, longer recovery times and slower turnover of soil water under urban trees raise the question of how the water supply for urban trees can be maintained if prolonged drought periods increasingly occur in the future. This is especially important as the UHI can increase PET and vegetation demand in urban areas compared to rural surroundings (Zipper et al., 2017). Upscaling these findings means that, in coming years, irrigation management is likely to be increasingly needed to support urban trees where soils are freely draining to prevent the depletion of soil storage after several years of consecutive drought conditions and the subsequent drought stress and potential loss of urban trees. This finding agrees with a recent remote-sensing-based study in California, where, even with irrigation strategies in place, urban trees seemed to be impacted more persistently by a multi-year drought than turfgrass, which showed a faster post-drought recovery (Miller et al., 2020). While our study further indicates that urban grassland will also require irrigation in order to preserve urban green spaces in warm and dry summers, we also found that urban shrubs may be more resilient. Taking such aspects into consideration for selecting suitable plant and tree species in the future will be crucial for the sustainable management of urban green spaces and limiting a city's water footprint (Nouri et al., 2019; Vico et al., 2014). As particularly the right combination of urban green and blue space can provide effective cooling mechanisms and ecosystem benefits (Gunawardena et al., 2017; Hathway and Sharples, 2012), Berlin with its high vegetation and water cover has exceptional potential for better use of these features.

Despite the preliminary insights from this study, it is clear that water partitioning in urban green spaces is complex, and more work is needed over longer timescales for a deeper understanding of ecohydrological partitioning under contrasting urban vegetation and upscaling these findings to the city scale. For more quantitative understanding of seasonal water cycling under the different vegetation types at our site, future work will integrate our field-based data into a process-based model (cf. Douinot et al., 2019). This will also help resolve the green water fluxes into estimates for interception, transpiration and soil evaporation (Smith et al., 2020). Although our spatially distributed soil sampling potentially covered the heterogeneity of urban soils within the plot-scale site, more extensive data collection will be required in the future, and we are currently undertaking similar sampling campaigns in urban parks across Berlin. Moreover, longer monitoring periods will inform on long-term trends under different extents of water stress and drought recovery over the next few years. These investigations will complement the results of this preliminary study and facilitate the upscaling of these results to the city scale. Eventually, this will lead to a more complete picture of how heterogeneously distributed urban vegetation alters urban water partitioning, using approaches that can be transferred to many other urban areas.

\section{Conclusions}

Through our plot-scale study of seasonal water cycling in Berlin-Steglitz, we gained insights into ecohydrological partitioning under different types of urban green spaces during prolonged dry periods and heavy precipitation events. Our results indicate that contrasting urban vegetation cover can significantly affect infiltration patterns and ET rates, as seen in variations in soil moisture regimes, isotopic signals and transit times. Despite high soil evaporation losses, urban grassland allowed for more direct percolation of rainwater and maintained higher moisture levels. Interception losses and vegetation water use contributed to similarly high ET under urban trees. Resulting from the high water demand of urban trees, soils at the tree site were driest and suggested a decoupled hydrological system with slower turnover times and recharge from the previous summer still present at depth. Shrubs seemed to exhibit lower soil evaporative losses compared to the grassland site and a higher moisture content through lower interception losses and root water uptake compared to the tree site, making this vegetation type potentially more resilient to persistent drought conditions. These insights can contribute to a better adaption of species-specific irrigation strategies in the future. However, more research is needed to upscale these findings to the city scale and gain more profound insights into the prevailing processes by integrating our field data into process-based ecohydrological models.

Data availability. The data that support the findings of this study are available from the corresponding author upon reasonable request. Data are also available on the FRED open-access database of IGB (Kuhlemann et al., 2020b).

Author contributions. The study was designed by LMK, DT and CS. Fieldwork and data collection were undertaken by LMK. Data were analysed by LMK, with ongoing discussion and inputs from DT, CS and AS. LMK prepared the draft manuscript, which subsequently all authors contributed to and edited.

Competing interests. The authors declare that they have no conflict of interest.

Special issue statement. This article is part of the special issue "Water, isotope and solute fluxes in the soil-plant-atmosphere interface: investigations from the canopy to the root zone". It is not associated with a conference. 
Acknowledgements. We thank the German Research Foundation (DFG) for funding this project as part of the Research Training Group "Urban Water Interfaces (UWI)" (GRK 2032/2) and the Einstein Foundation for the support as part of the project "Modelling surface and groundwater with isotopes in urban catchments (MOSAIC)". We are especially thankful to our colleagues of the TU Berlin Ecology Department for providing access to their property and assistance for site selection, in particular Birgit Seitz, and to the Department of Climatology, especially Dieter Scherer and Fred Meier, for providing the UCO climate data. Further, we thank our colleagues Esther Brakkee, Larissa Lachmann, Nina-Sophie Weiß, Christian Marx, Lukas Kleine, Wiebke Lehmann, Hauke Dämpfling, David Dubbert, Anna Wieland, Jonas Freymüller, Sylvia Jordan and Mikael Gillefalk for assistance in the sampling and installation of equipment and David Dubbert for help with the isotope analysis. Finally, we thank the Berlin Senate Department for the Environment, Transport and Climate Protection for providing groundwater data and well access.

Financial support. This research has been funded by the Deutsche Forschungsgemeinschaft (grant no. GRK 2032/2).

The publication of this article was funded by the Open Access Fund of the Leibniz Association.

Review statement. This paper was edited by Miriam CoendersGerrits and reviewed by two anonymous referees.

\section{References}

Allen, R. G., Pereira, L. S., Raes, D., and Smith, M.: Crop evapotranspiration - Guidelines for computing crop water requirements, FAO Irrigation and drainage paper 56, FAO - Food and Agriculture Organization of the United Nations, Rome, 1998.

Allen, S. T., Kirchner, J. W., Braun, S., Siegwolf, R. T. W., and Goldsmith, G. R.: Seasonal origins of soil water used by trees, Hydrol. Earth Syst. Sci., 23, 1199-1210, https://doi.org/10.5194/hess-23-1199-2019, 2019.

Amt für Statistik Berlin-Brandenburg: Bevölkerungsstand 2018, available at: https://www.statistik-berlin-brandenburg.de/ BasisZeitreiheGrafik/Bas-Bevoelkerungsstand.asp?Ptyp=300\& Sageb $=12015 \&$ creg=BBB\&anzwer $=6$, last access: $10 \mathrm{Au}-$ gust 2020 .

Asawa, T., Kiyono, T., and Hoyano, A.: Continuous measurement of whole-tree water balance for studying urban tree transpiration, Hydrol. Process, 31, 3056-3068, https://doi.org/10.1002/hyp.11244, 2017.

Bijoor, N. S., McCarthy, H. R., Zhang, D., and Pataki, D. E.: Water sources of urban trees in the Los Angeles metropolitan area, Urban Ecosyst., 15, 195-214, https://doi.org/10.1007/s11252-0110196-1, 2011.

Bornkamm, R. and Köhler, M.: Ein Naturgarten für Lehre und Forschung: Der Garten des Instituts für Ökologie der Technischen Universität Berlin, Landschaftsentwicklung und Umweltforschung, Schriftenreihe des Fachbereichs Landschaftsentwicklung an der TU Berlin, 1987 (in German).
Buras, A., Rammig, A., and Zang, C. S.: Quantifying impacts of the 2018 drought on European ecosystems in comparison to 2003, Biogeosciences, 17, 1655-1672, https://doi.org/10.5194/bg-171655-2020, 2020.

Clark, I. and Fritz, P.: Environmental Isotopes in Hydrogeology, Lewis Publishers, CRC Press LLC, Boca Raton, Florida, 1997.

Dansgaard, W.: Stable Isotopes in Precipitation, Tellus, 16, 436468, 1964.

Douinot, A., Tetzlaff, D., Maneta, M., Kuppel, S., Schulte-Bisping, H., and Soulsby, C.: Ecohydrological modelling with Ech2O-iso to quantify forest and grassland effects on water partitioning and flux ages, Hydrol. Process., 33, 2174-2191, https://doi.org/10.1002/hyp.13480, 2019.

Deutscher Wetterdienst (DWD): Climate Data Center (CDC), available at: https://opendata.dwd.de/climate_environment/ CDC/observations_germany/climate/daily/kl/, last access: 10 August 2020a.

Deutscher Wetterdienst (DWD): Vieljährige Mittelwerte, available at: https://www.dwd.de/DE/leistungen/klimadatendeutschland/ vielj_mittelwerte.html, last access: 10 August 2020b.

Ehleringer, J. R., Barnette, J. E., Jameel, Y., Tipple, B. J., and Bowen, G. J.: Urban water - a new frontier in isotope hydrology, Isotopes Environ. Health Stud., 52, 477-486, https://doi.org/10.1080/10256016.2016.1171217, 2016.

Endreny, T. A.: Land Use and Land Cover Effects on Runoff Processes: Urban and Suburban Development, Encyclopedia of hydrological Sciences, John Wiley \& Sons, Ltd., 2005.

Fletcher, T. D., Andrieu, H., and Hamel, P.: Understanding, management and modelling of urban hydrology and its consequences for receiving waters: A state of the art, Adv. Water Resour., 51, 261279, https://doi.org/10.1016/j.advwatres.2012.09.001, 2013.

Friedrich, K. and Kasper, F.: Rückblick auf das Jahr 2018 - das bisher wärmste Jahr in Deutschland, Deutscher Wetterdienst, Abteilung Klimaüberwachung, 2019.

Geodaten der Deutschen Landesvermessung (GeoBasis-DE)/ Bundesamt für Kartographie und Geodäsie (BKG): Digitale Geodaten, 2013.

Geoportal Berlin: Digitale farbige Orthophotos 2018 (DOP20RGB), available at: https://fbinter.stadt-berlin.de/ fb/berlin/service_intern.jsp?id=a_luftbild2018_rgb@senstadt\& type=FEED (last access: 3 March 2020), 2018.

Geris, J., Tetzlaff, D., McDonnell, J., and Soulsby, C.: The relative role of soil type and tree cover on water storage and transmission in northern headwater catchments, Hydrol. Process., 29, 1844 1860, https://doi.org/10.1002/hyp.10289, 2015.

Gerstengarbe, F.-W., Badeck, F., Hattermann, F., Krysanova, V., Lahmer, W., Lasch, P., Stock, M., Suckow, F., Wechsung, F., and Werner, P. C.: Studie zur klimatischen Entwicklung im Land Brandenburg bis 2055 und deren Auswirkungen auf den Wasserhaushalt, die Forst- und Landwirtschaft sowie die Ableitung erster Perspektiven, Potsdam Institute for Climate Impact Research (PIK), 2003 (in German).

Gessner, M. O., Hinkelmann, R., Nützmann, G., Jekel, M., Singer, G., Lewandowski, J., Nehls, T., and Barjenbruch, M.: Urban water interfaces, J. Hydrol., 514, 226-232, https://doi.org/10.1016/j.jhydrol.2014.04.021, 2014.

Gómez-Navarro, C., Pataki, D. E., Bowen, G. J., and Oerter, E. J.: Spatiotemporal variability in water sources of urban soils and 
trees in the semiarid, irrigated Salt Lake Valley, Ecohydrology, 12, e2154, https://doi.org/10.1002/eco.2154, 2019.

Gralher, B., Herbstritt, B., Weiler, M., Wassenaar, L. I., and Stumpp, C.: Correcting for Biogenic Gas Matrix Effects on Laser-Based Pore Water-Vapor Stable Isotope Measurements, Vadose Zone J., 17, 1-10, https://doi.org/10.2136/vzj2017.08.0157, 2018.

Granier, A.: Evaluation of transpiration in a Douglas-fir stand by means of sap flow measurements, Tree Physiol., 3, 309-320, https://doi.org/10.1093/treephys/3.4.309, 1987.

Gunawardena, K. R., Wells, M. J., and Kershaw, T.: Utilising green and bluespace to mitigate urban heat island intensity, Sci. Total Environ., 584-585, 1040-1055, https://doi.org/10.1016/j.scitotenv.2017.01.158, 2017.

Gupta, H. V., Kling, H., Yilmaz, K. K., and Martinez-Baquero, G. F.: Decomposition of the Mean Squared Error and NSE Performance Criteria: Implications for Improving Hydrological Modelling, J. Hydrol., 377, 80-91, 2009.

Hathway, E. A. and Sharples, S.: The interaction of rivers and urban form in mitigating the Urban Heat Island effect: A UK case study, Build. Environ., 58, 14-22, https://doi.org/10.1016/j.buildenv.2012.06.013, 2012.

Hendry, M. J., Schmeling, E., Wassenaar, L. I., Barbour, S. L., and Pratt, D.: Determining the stable isotope composition of pore water from saturated and unsaturated zone core: improvements to the direct vapour equilibration laser spectrometry method, Hydrol. Earth Syst. Sci., 19, 4427-4440, https://doi.org/10.5194/hess-19-4427-2015, 2015.

Hughes, C. E. and Crawford, J.: A new precipitation weighted method for determining the meteoric water line for hydrological applications demonstrated using Australian and global GNIP data, J. Hydrol., 464-465, 344-351, https://doi.org/10.1016/j.jhydrol.2012.07.029, 2012.

Kendall, C. and McDonnell, J.: Isotope Tracers in Catchment Hydrology, 1 ed., Elsevier Science B.V., Amsterdam, the Netherlands, 1998.

Kleine, L., Tetzlaff, D., Smith, A., Wang, H., and Soulsby, C.: Using water stable isotopes to understand evaporation, moisture stress, and re-wetting in catchment forest and grassland soils of the summer drought of 2018, Hydrol. Earth Syst. Sci., 24, 3737-3752, https://doi.org/10.5194/hess-24-3737-2020, 2020.

Kuhlemann, L. M., Tetzlaff, D., and Soulsby, C.: Urban water systems under climate stress: An isotopic perspective from Berlin, Germany, Hydrol. Process., 34, 3758-3776, https://doi.org/10.1002/hyp.13850, 2020a.

Kuhlemann, L.-M., Tetzlaff, D., Smith, A., Kleinschmit, B., and Soulsby, C.: Soil Moisture data for grassland, shrub and trees at the Steglitz Urban Ecohydrological Observatory, https://doi.org/10.18728/566.0, 2020b.

Langendijk, G. S., Rechid, D., and Jacob, D.: Urban Areas and Urban-Rural Contrasts under Climate Change: What Does the EURO-CORDEX Ensemble Tell Us? - Investigating near Surface Humidity in Berlin and Its Surroundings, AtmosphereBasel, 10, 730, https://doi.org/10.3390/atmos10120730, 2019.

Lansu, E. M., van Heerwaarden, C. C., Stegehuis, A. I., and Teuling, A. J.: Atmospheric Aridity and Apparent Soil Moisture Drought in European Forest During Heat Waves, Geophys. Res. Lett., 47, e2020GL087091, https://doi.org/10.1029/2020GL087091, 2020.
Limberg, A. and Thierbach, J.: Gliederung der Grundwasserleiter in Berlin, Brandenburgische Geowissenschaftliche Beiträge, 4, 21-26, 1997 (in German).

Limberg, A.: Grundwasser in Berlin: Vorkommen - Nutzung - Schutz - Gefährdung, Berlin Senate (Senatsverwaltung für Gesundheit, Umwelt und Verbraucherschutz (SenGUV)), Berlin, 2007.

McGrane, S. J.: Impacts of urbanisation on hydrological and water quality dynamics, and urban water management: a review, Hydrol. Sci. J., 61, 2295-2311, https://doi.org/10.1080/02626667.2015.1128084, 2016.

McGuire, K. J. and McDonnell, J. J.: A review and evaluation of catchment transit time modeling, J. Hydrol., 330, 543-563, https://doi.org/10.1016/j.jhydrol.2006.04.020, 2006.

Miller, D. L., Alonzo, M., Roberts, D. A., Tague, C. L., and McFadden, J. P.: Drought response of urban trees and turfgrass using airborne imaging spectroscopy, Remote Sens. Environ., 240, 111646, https://doi.org/10.1016/j.rse.2020.111646, 2020.

Möller, K. and Burgschweiger, J.: Wasserversorgungskonzept für Berlin und für das von den BWB versorgte Umland (Entwicklung bis 2040), Report for the Berliner Wasserbetriebe (BWB), Berlin, 2008.

Nouri, H., Beecham, S., Kazemi, F., and Hassanli, A. M.: A review of ET measurement techniques for estimating the water requirements of urban landscape vegetation, Urban Water J., 10, 247 259, https://doi.org/10.1080/1573062x.2012.726360, 2013.

Nouri, H., Glenn, E., Beecham, S., Chavoshi Boroujeni, S., Sutton, P., Alaghmand, S., Noori, B., and Nagler, P.: Comparing Three Approaches of Evapotranspiration Estimation in Mixed Urban Vegetation: Field-Based, Remote SensingBased and Observational-Based Methods, Remote Sens., 8, 492, https://doi.org/10.3390/rs8060492, 2016.

Nouri, H., Chavoshi Borujeni, S., and Hoekstra, A. Y.: The blue water footprint of urban green spaces: An example for Adelaide, Australia, Landscape Urban Plan., 190, 103613, https://doi.org/10.1016/j.landurbplan.2019.103613, 2019.

Oerter, E. J. and Bowen, G.: In situ monitoring of $\mathrm{H}$ and $\mathrm{O}$ stable isotopes in soil water reveals ecohydrologic dynamics in managed soil systems, Ecohydrology, 10, e1841, https://doi.org/10.1002/eco.1841, 2017.

Oerter, E. J. and Bowen, G. J.: Spatio-temporal heterogeneity in soil water stable isotopic composition and its ecohydrologic implications in semiarid ecosystems, Hydrol. Process., 33, 1724-1738, https://doi.org/10.1002/hyp.13434, 2019.

Pataki, D. E., Boone, C. G., Hogue, T. S., Jenerette, G. D., McFadden, J. P., and Pincetl, S.: Socio-ecohydrology and the urban water challenge, Ecohydrology, 4, 341-347, https://doi.org/10.1002/eco.209, 2011a.

Pataki, D. E., McCarthy, H. R., Litvak, E., and Pincetl, S.: Transpiration of urban forests in the Los Angeles metropolitan area, Ecol. Appl., 21, 661-677, 2011 b.

Peters, E. B., Hiller, R. V., and McFadden, J. P.: Seasonal contributions of vegetation types to suburban evapotranspiration, J. Geophys. Res., 116, https://doi.org/10.1029/2010jg001463, 2011.

Schirmer, M., Leschik, S., and Musolff, A.: Current research in urban hydrogeology - A review, Adv. Water Resour., 51, 280-291, https://doi.org/10.1016/j.advwatres.2012.06.015, 2013.

Senate Department for Urban Development (SenStadt): Berlin Environmental Atlas: Map 02.07 - Depth to the Wa- 
ter Table, available at: https://www.stadtentwicklung.berlin.de/ umwelt/umweltatlas/eid207.htm (last access: 10 August 2020), 2010a.

Senate Department for Urban Development (SenStadt): Berlin Environmental Atlas: Map 01.08 - Terrain Elevations, available at: https://fbinter.stadt-berlin.de/fb/index.jsp?loginkey=showMap\& mapId=ek01_08dgm2009@esenstadt\&Szenario=fb_en (last access: 10 August 2020), 2010b.

Senate Department for Urban Development and Housing (SenStadtWoh): Berlin Environmental Atlas: Map 01.02 Impervious Soil Coverage (Sealing of Soil Surface), Accompanying text, available at: https://www.stadtentwicklung.berlin. de/umwelt/umweltatlas/e_text/ekd102.pdf (last access: $10 \mathrm{Au}$ gust 2020), 2017.

Senate Department for Urban Development and Housing (SenStadtWoh): Berlin Environmental Atlas: Map 01.06 - Soil-Scientific Characteristic Values, available at: https://fbinter.stadt-berlin.de/fb/index.jsp?loginkey=showMap\& mapId=wmsk01_06_01bodart2015@senstadt (last access: 21 August 2020), 2018.

Senate Department for Urban Development and Housing (SenStadtWoh): Berlin Environmental Atlas, Map 02.13: Surface Runoff, Percolation, Total Runoff and Evaporation from Precipitation, Accompanying text, available at: https://www.stadtentwicklung. berlin.de/umwelt/umweltatlas/e_text/ekd213.pdf (last access: 10 December 2020), 2019.

Senate Department for the Environment, Transport and Climate Protection (SenUVK): Grünflächeninformationssystem (GRIS): Anteil öffentlicher Grünflächen in Berlin, available at: https://www.berlin.de/senuvk/umwelt/stadtgruen/gruenanlagen/ de/daten_fakten/downloads/ausw_5.pdf (last access: $10 \mathrm{Au}-$ gust 2020), 2019a.

Senate Department for the Environment, Transport and Climate Protection (SenUVK): Grünflächeninformationssystem (GRIS): Öffentliche Grünflächen in Berlin Flächenübersicht der Bezirke, 31.12.2019, available at: https://www.berlin.de/senuvk/umwelt/stadtgruen/gruenanlagen/ de/daten_fakten/downloads/ausw_13.pdf (last access: $10 \mathrm{Au}-$ gust 2020), 2019b.

Senate Department for the Environment, Transport and Climate Protection (SenUVK), Dept. Integrativer Umweltschutz, Landesgeologie II B 3: Grundwaserstände, Berlin, 2020.

Smith, A., Tetzlaff, D., Kleine, L., Maneta, M. P., and Soulsby, C.: Isotope-aided modelling of ecohydrologic fluxes and water ages under mixed land use in Central Europe: The 2018 drought and its recovery, Hydrol. Process., 34, 3406-3425, https://doi.org/10.1002/hyp.13838, 2020.

Soulsby, C., Braun, H., Sprenger, M., Weiler, M., and Tetzlaff, D.: Influence of forest and shrub canopies on precipitation partitioning and isotopic signatures, Hydrol. Process., 31, 4282-4296, https://doi.org/10.1002/hyp.11351, 2017.

Sprenger, M., Leistert, H., Gimbel, K., and Weiler, M.: Illuminating hydrological processes at the soil-vegetation-atmosphere interface with water stable isotopes, Rev. Geophys., 54, 674-704, https://doi.org/10.1002/2015rg000515, 2016.
Sprenger, M., Tetzlaff, D., and Soulsby, C.: Soil water stable isotopes reveal evaporation dynamics at the soil-plant-atmosphere interface of the critical zone, Hydrol. Earth Syst. Sci., 21, 3839 3858, https://doi.org/10.5194/hess-21-3839-2017, 2017.

Sprenger, M., Llorens, P., Cayuela, C., Gallart, F., and Latron, J.: Mechanisms of consistently disjunct soil water pools over (pore) space and time, Hydrol. Earth Syst. Sci., 23, 2751-2762, https://doi.org/10.5194/hess-23-2751-2019, 2019a.

Sprenger, M., Stumpp, C., Weiler, M., Aeschbach, W., Allen, S. T., Benettin, P., Dubbert, M., Hartmann, A., Hrachowitz, M., Kirchner, J. W., McDonnell, J., Orlowski, N., Penna, D., Pfahl, S., Rinderer, M., Rodriguez, N., Schmidt, M., and Werner, C.: The Demographics of Water: A Review of Water Ages in the Critical Zone, Rev. Geophys., 57, 800-834, https://doi.org/10.1029/2018RG000633, 2019b.

Stackebrandt, W. and Manhenke, V.: Geologie und Geopotenziale in Brandenburg, in: Atlas zur Geologie von Brandenburg, 4. aktualisierte Auflage, Landesamt für Bergbau, Geologie und Rohstoffe Brandenburg (LBGR), Cottbus, 2010.

Stumpp, C., Klaus, J., and Stichler, W.: Analysis of long-term stable isotopic composition in German precipitation, J. Hydrol., 517, 351-361, https://doi.org/10.1016/j.jhydrol.2014.05.034, 2014.

Vico, G., Revelli, R., and Porporato, A.: Ecohydrology of street trees: design and irrigation requirements for sustainable water use, Ecohydrology, 7, 508-523, https://doi.org/10.1002/eco.1369, 2014.

von Freyberg, J., Allen, S. T., Seeger, S., Weiler, M., and Kirchner, J. W.: Sensitivity of young water fractions to hydro-climatic forcing and landscape properties across 22 Swiss catchments, Hydrol. Earth Syst. Sci., 22, 3841-3861, https://doi.org/10.5194/hess-223841-2018, 2018.

Wang, H., Tetzlaff, D., Dick, J. J., and Soulsby, C.: Assessing the environmental controls on Scots pine transpiration and the implications for water partitioning in a boreal headwater catchment, Agr. Forest Meteorol., 240-241, 58-66, https://doi.org/10.1016/j.agrformet.2017.04.002, 2017.

Wassenaar, L. I., Hendry, M. J., Chostner, V. L., and Lis, G. P.: High Resolution Pore Water $\delta 2 \mathrm{H}$ and $\delta 18 \mathrm{O}$ Measurements by H2O(liquid)-H2O(vapor) Equilibration Laser Spectroscopy, Environ. Sci. Technol., 42, 9262-9267, 2008.

Zipper, S. C., Schatz, J., Singh, A., Kucharik, C. J., Townsend, P. A., and Loheide, S. P.: Urban heat island impacts on plant phenology: intra-urban variability and response to land cover, Environ. Res. Lett., 11, 054023, https://doi.org/10.1088/17489326/11/5/054023, 2016.

Zipper, S. C., Schatz, J., Kucharik, C. J., and Loheide, S. P.: Urban heat island-induced increases in evapotranspirative demand, Geophys. Res. Lett., 44, 873-881, https://doi.org/10.1002/2016gl072190, 2017. 